Florida International University FIU Digital Commons

\title{
Mercury characterization in soil collected nearby the Department of Energy Oak Ridge reservation
}

Julio Cesar Cabrera

Florida International University

DOI: $10.25148 /$ etd.FI14052520

Follow this and additional works at: https://digitalcommons.fiu.edu/etd

Part of the Environmental Chemistry Commons

\section{Recommended Citation}

Cabrera, Julio Cesar, "Mercury characterization in soil collected nearby the Department of Energy Oak Ridge reservation" (2009). FIU Electronic Theses and Dissertations. 1956.

https://digitalcommons.fiu.edu/etd/1956 
Miami, Florida

\section{MERCURY CHARACTERIZATION IN SOIL COLLECTED NEARBY THE DEPARTMENT OF ENERGY OAK RIDGE RESERVATION}

A thesis submitted in partial fulfillment of the

requirements for the degree of

MASTER OF SCIENCE

in

CHEMISTRY

by

Julio Cesar Cabrera

2009 
To: Dean Kenneth Furton

College of Arts and Sciences

This thesis, written by Julio Cesar Cabrera, and entitled Mercury Characterization in Soil Collected Nearby the Department of Energy Oak Ridge Reservation, having been approved in respect to style and intellectual content, is referred to you for judgment.

We have read this thesis and recommend that it be approved.

Konstantinos Kavallieratos

$\overline{\text { Rudolf Jaffe }}$

Yong Cai, Major Professor

Date of Defense: March 6, 2009

The thesis of Julio Cesar Cabrera is approved.

Dean Kenneth Furton

College of Arts and Sciences

Dean George Walker

University Graduate School

Florida International University, 2009 


\section{DEDICATION}

To my family, for all their unconditional love and support and to the memory of my father. 


\section{ACKNOWLEDGMENTS}

I thank my major Professor Dr. Yong Cai, for his guidance, for his suggestions through my graduate studies and for the financial support through a research assistantship. I also owe gratitude to Guangliang Liu for his help in and outside the lab. I would also like to thank to Marshall Allen for his support in throughout the project.

I would like to thank Dr. Rudolf Jaffe and Dr. Konstantinos Kavallieratos for their support and understanding. 
ABSTRACT OF THE THESIS

MERCURY CHARACTERIZATION IN SOIL COLLECTED NEARBY THE

DEPARTMENT OF ENERGY OAK RIDGE RESERVATION

by

Julio Cesar Cabrera

Florida International University, 2009

Miami, Florida

Professor Yong Cai, Major Professor

Total mercury $(\mathrm{Hg})$ concentration provides insufficient information to understand $\mathrm{Hg}$ behavior in $\mathrm{Hg}$-contaminated soil systems and to seek potential remediation technologies, because the distribution, mobility, bioavailability, and toxicity of $\mathrm{Hg}$ are dependent on $\mathrm{Hg}$ forms present in soils. The phase association of $\mathrm{Hg}$ in soil is investigated to evaluate potential environmental risk through combination of total $\mathrm{Hg}$ determination, soil fractionation, and speciation analysis of $\mathrm{Hg}$ in a $\mathrm{Hg}$-contaminated DOE site. Besides total $\mathrm{Hg}$ concentration analysis, sequential extraction procedures and thermal desorption techniques were employed to study $\mathrm{Hg}$ binding forms in soils in this study. Total mercury concentrations ranging from less than $100 \mathrm{ng} / \mathrm{g}$ to more than 30,000 $\mathrm{ng} / \mathrm{g}$ were detected. The highest form of mercury present in the soil is organically-bound mercury, followed by elemental mercury, and mercury sulfide. Bioavailable and mobile mercury is minimal. 


\section{TABLE OF CONTENTS}

CHAPTER

PAGE

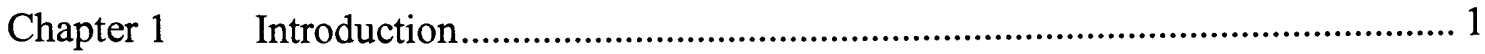

1.1 Mercury contamination in the environment.................................................... 1

1.2 Sources of mercury in the environment .......................................................... 5

1.3 Biogeochemical cycling of mercury ……...................................................... 7

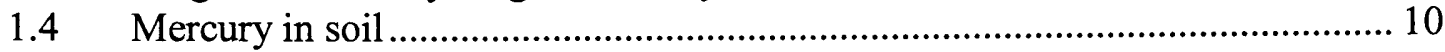

1.5 Mercury problems in Oak Ridge Reservation ............................................... 12

1.6 Research Objectives.................................................................................. 13

Chapter 2 Mercury speciation in Oak Ridge Reservation soil .................................. 14

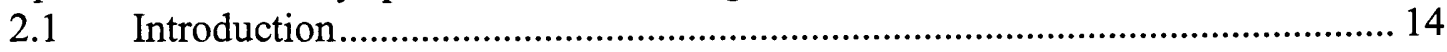

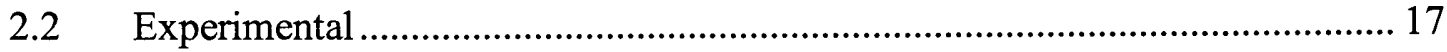

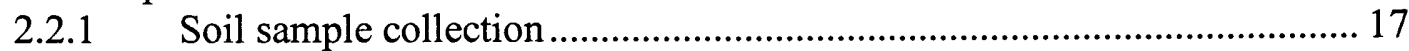

2.2.2 Fractionation of soil sample................................................................... 17

2.2.3 Reagents and instrumentation ............................................................... 19

2.2.4 Determination of $\mathrm{Hg}$ in fractionated samples .......................................... 20

2.2.5 Thermal desorption experiments.............................................................. 20

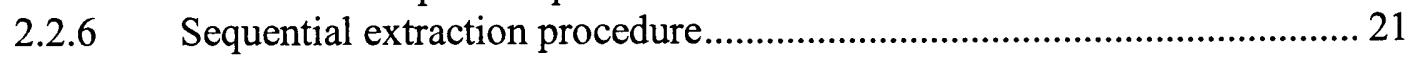

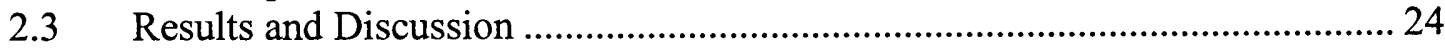

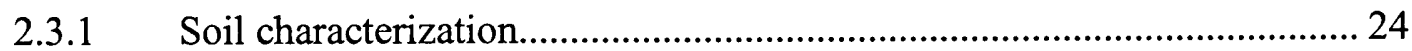

2.3.2 $\mathrm{Hg}$ in the redoximorphic depletions and redoximorphic concentrations with different particle sizes .......................................................................................... 25

2.3.3 Thermal desorption experiments............................................................. 27

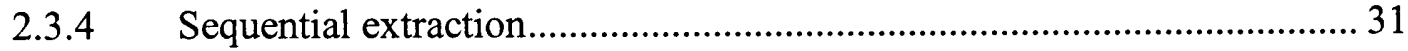

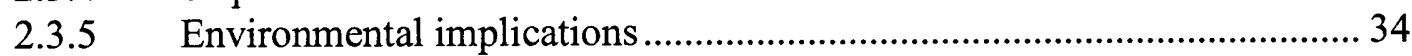

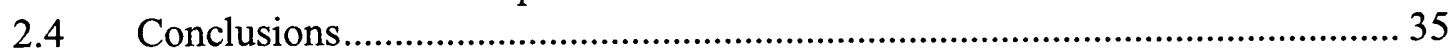

Chapter 3 Analysis of mercury species in samples from ORR ............................... 37

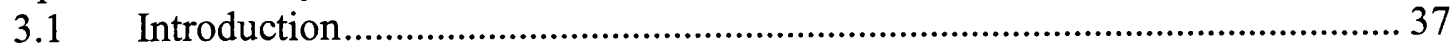

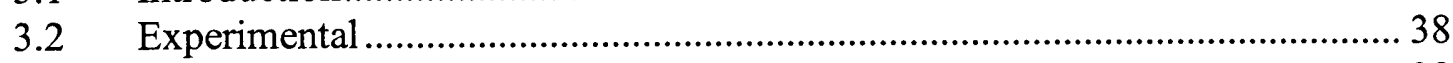

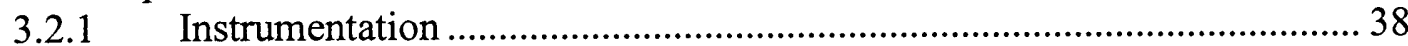

3.2.2 Chemicals and Reagents …............................................................... 38

3.2.3 Sampling site selection ...................................................................... 40

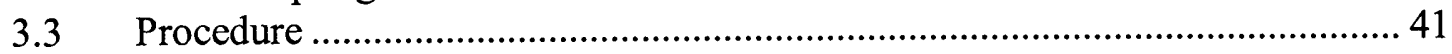

3.3.1 Total mercury in soil and sediment......................................................... 41

3.3.2 Total mercury in water.......................................................................... 41

3.3.3 Methylmercury in soil and sediment..................................................... 43

3.4 Results and Discussion ................................................................................ 44

3.4.1 Initial evaluation of total mercury concentrations in ORR area ............... 44

3.4.2 Survey of the mercury problem in the ORR area .................................... 46

3.4.3 Methylmercury in ORR soil and sediment ............................................. 48

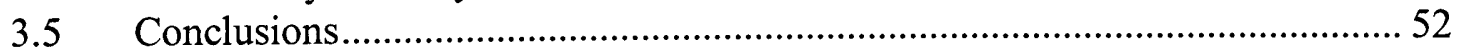




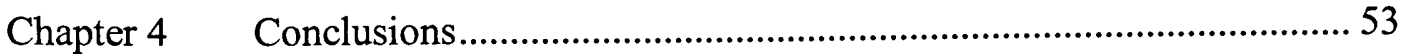

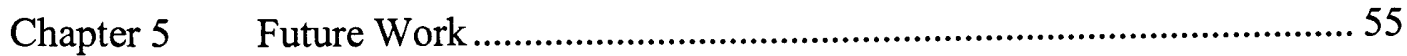

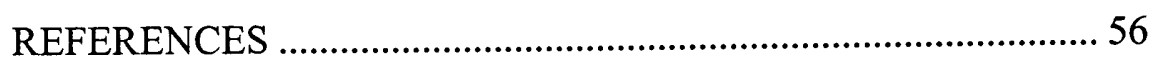


TABLE

PAGE

Table 2.1 Extractants and $\mathrm{Hg}$ fractions used in the sequential extraction procedure....

Table 2.2 Content of major elements and organic carbon in fractionated subsamples.

Table 2.3 Hg concentrations in the redoximorphic depletions and redoximorphic concentration from the ORR soil sample with different particle size .26

Table 2.4 Concentrations of different $\mathrm{Hg}$ species in different fractions of the ORR soil and SRM NIST 8406 by using sequential extraction procedure

Table 3.1 Total mercury concentrations in ORR samples during initial sampling event.

Table 3.2 Mercury concentrations in the selected soil, sediment, and water samples collected from Oak Ridge LEFPC mercury-contaminates samples........47

Table 3.3 Methylmercury concentrations in ORR soil and sediment samples.......50 


\section{LIST OF FIGURES}

FIGURE

PAGE

Figure 1.1 The mercury cycle. Sources and fate. Hgp refers to mercury in the particulate. .8

Figure 1.2 Diagram summarizing the biogeochemical cycling of mercury in aquatic environments. $\mathrm{M}^{\mathrm{a}}=$ methylation (oxidative) $\mathrm{D}^{\mathrm{b}}=$ demethylation (bacterial reduction)

Figure 2.1 Redoximorphic depletions (gray color) and redoximorphic concentrations (brown color) in Y-12 soil sample.

Figure 2.2 A scheme showing the sequential extraction procedure used in this study....

Figure 2.3 $\mathrm{Hg}$ concentration in the ORR soil sample and SRM NIST 8406 after thermal desorption treatments. ...

Figure 2.4 Distribution of $\mathrm{Hg}$ in the freeze-dried subsamples from the ORR soil sample and the SRM NIST8406 using sequential extraction

Figure 3.1 Sampling points along the LEFPC

Figure 3.2 Distribution of MeHg in soil and sediment along the EFPC .51

Figure 3.3 Distribution of Thg in soil and sediment along the EFPC 52 
ABBREVIATION

$\AA$

AAS

CVAFS

DOE

EFPC

EPA

$\mathrm{Hg}$

$\mathrm{Hg}^{(0)}$

$\mathrm{HgCl}_{2}$

$\mathrm{HgS}$

ICPMS

LEFPC

$\mathrm{MeHg}$

MMHg

NIST

ORR

ppt
MEANING

armstrong

atomic absorption spectrometry

cold vapor atomic fluorescence

Department of Energy

East Fork Poplar Creek

Enviromental Protection Agency

mercury

elemental mercury

mercury chloride

mercury sulfide

Inductively Coupled Mass Spectrometry

Lower East Fork Poplar Creek

Methyl mercury

monomethyl mercury

National Institute of Standards and Technology

Oak Ridge Reservation

parts per trillion 
SEP

SRM

THg sequential extraction procedure

Standard Reference Material

Total mercury 


\section{Chapter 1 Introduction}

1.1 Mercury contamination in the environment.

Mercury is a liquid metal at ambient temperatures and pressures. It forms salts in two ionic states: mercury (I) and mercury (II). Mercury (II) salts are much more common in the environment, and if soluble in water are bioavailable and considered toxic. Mercury also forms organometallic compounds, many of which have industrial and agricultural uses. Elementary mercury gives rise to a vapor that is only slightly soluble in water, but is problematic because of easy transport in the atmosphere. The most common form of mercury is insoluble mercury (II) sulfide (naturally occurring cinnabar) which is less bioavailable than other forms. (Nriagu, 1993, 1994; Pirrone, 2001; Renneberg and Dudas, 2001). In contrast to many other metal/metalloid contaminants, mercury displays a complex environmental speciation behavior. Widespread, detectable environmental mercury species include divalent mercury $\left(\mathrm{Hg}^{2+}\right)$, elemental mercury $\left(\mathrm{Hg}^{0}\right)$ and monomethylmercury $\left(\mathrm{CH}_{3} \mathrm{Hg}^{+}\right)$(Akagi, 2000; Schroeder, 1989). Less frequently encountered compounds include dimethylmercury (Mason, 1994), monovalent mercury $\left(\mathrm{Hg}_{2}{ }^{2+}\right.$, a species that disproportionates via the following reaction: $\mathrm{Hg}_{2}{ }^{2+} \rightarrow \mathrm{Hg}^{2+}+\mathrm{Hg}$ (Pehkonen, 1989). More recently, detectable quantities of ethylmercury compounds (e.g., $\mathrm{C}_{2} \mathrm{H}_{5} \mathrm{Hg}^{+}, \mathrm{C}_{2} \mathrm{H}_{5} \mathrm{HgC}_{2} \mathrm{H}_{5}$, etc.) have been reported in environmental media (Cai, 1997; Hintelmann et al., 1995; Holmes and Lean, 2006; Siciliano et al., 2003).

Elemental mercury is known to be globally transported before it is deposited on soil or water (Pilgrim et al., 2001). Mercury contamination has long been recognized as a problem for both humans and ecosystems. Mercury is considered by the United States Environmental Protection Agency (EPA) to be a highly dangerous element because 
methylated mercury is accumulative and persistent in the environment and biota. Since mercury does not degrade once it is released to the environment it will always be present in one form or another (U.S.E.P.A., 2000). Mercury in natural waters is mostly in the form of inorganic species; however, its biological toxic effects are primarily due to methylmercury (Agency for Toxic Substances and Disease Registry (ATSDR), 1999; Clarkson, 1972, 1992; Clarkson and Magos, 2006; Clarkson and Strain, 2003). Unfortunately, the inorganic mercury released into the environment can be converted, by naturally-occurring biological processes, into methylmercury species. Methylmercury is a highly toxic organomercury species, present in much lower concentrations and is readily accumulated by aquatic organisms (Cai et al., 1996; Liu et al., 2008a; Liu et al., 2008b; Mason, 1994; Mason and Benoit, 2003; Mason et al., 1993; Sanchez-Uria, 1998; Ullrich et al., 2007; Ullrich et al., 2001; USEPA, 2002)

Methylmercury is neurotoxic, causes blockage of binding sites of enzymes, interferes with protein synthesis, impedes thymidine incorporation into DNA, among other factors (Clarkson, 1992; Halbach, 1995; National Institute of Environmental Health Science (NIEHS), 1998; National Research Council (NRC), 2000; Thayer, 1984). The short chain alkylmercury compounds are toxic and tend to bioaccumulate more readily than other species of mercury. The mercury-carbon bond is very stable, and the presence of the alkyl groups confers lipid solubility. Nearly all mercury found in fish flesh ( $>95 \%)$ occurs as methylmercury (Cai et al., 2000; Mason et al., 1999; Porcella, 1994), and most of the mercury present in humans originates from fish in the food supply (U.S.E.P.A., 2000) via the following processes: (1) emission of mercury to the air; (2) mercury air transport and deposition on land and water; (3) transformation of mercury to 
methylmercury in water bodies; (4) methylmercury uptake and bioaccumulation in fish; and (5) consumption of contaminated fish by mammals, including humans. Mercury and methylmercury exposures can result in permanent damage to the brain and kidneys, in both humans and wildlife. Many organizations and agencies have addressed the level of methylmercury exposure to humans (NRC, 2000; U.S.E.P.A., 2000).

Several pollution events have been associated with the anthropogenic use of organomercurials. The most documented case of methylmercury poisoning occurred in Minamata Bay, Japan (from 1932 until diagnosed in 1968), from which the name Minamata Disease derived (Clarkson, 1972, 1992; Hosokawa, 1993; Smith, 1975). More than 2,000 people were poisoned by the consumption of fish and shellfish contaminated with methylmercury. This event was the first known case of mercury pollution in the aquatic environment. It was caused by the discharge of methylmercury into the drainage channel that leads into the Minamata Bay. Methylmercury was formed during the production of PVC formed by reacting acetaldehyde and inorganic mercury used as a catalyst. Also organomercurials were used as fungicides for cereal infections in the 1960's. This use of organomercurials caused a particularly disastrous outbreak in 1972 in Iraq, where the seed grain coated with antifungal methylmercuric preparations were consumed as homemade bread. As a result 6,530 victims were ill (Watanabe, 1996). The impact on ecological systems was noted earlier in 1964 by Swedish ornithologists who observed a significant decrease in wild bird populations (Helander, 1982). Nowadays the pathway of exposure to methylmercury involves the emission of low concentrations of mercury, mainly from combustion sources (Environmental Reporter, 2000; Fitzgerald et al., 2007; Fitzgerald and Lyons, 1973; Fitzgerald and Watras, 1989; Lindberg et al., 
2005a; Lindberg et al., 2005b; Mason et al., 2006; Nriagu et al., 1992). These emissions lead to build up of methylmercury in water bodies and fish tissue over time (U.S.E.P.A., 1997e1997f; U.S.G.S., 1998). It is important to stress that the most likely individuals who are being exposed to a high level of methylmercury are consumers of large quantities of fish. Pregnant women and young children are particularly sensitive to exposure of high levels of mercury (NRC, 2000).

During the past decade, a new trend has emerged with regards to mercury pollution (Kambey, 1989). Investigations initiated in the late 1980s in the northern-tier states of the United States, Canada and the Nordic countries found that fish, mainly from oligotrophic lakes and often in very remote areas, commonly have high levels of mercury (Cai, 1997; Cai, 2000; Cai et al., 1997; Cai et al., 1999; Krabbenhoft et al., 1998; Krabbenhoft et al., 2000; Kranzer, 2003; Lindberg et al., 2001; Lindberg and Zhang, 2000; Liu et al., 2008a; Liu et al., 2008b; Mason, 1994; Mason et al., 2005; Mason and Benoit, 2003; Mason et al., 2000; Mason and Sullivan, 1997; O'Driscoll and Evans, 2000; O'Driscoll et al., 2005). Fish sampling surveys in other regions of the United States have shown widespread mercury contamination in streams, wetlands, reservoirs and lakes (U.S.G.S., 1998). Most of the mercury released to the atmosphere by anthropogenic activities is in the form of the elemental mercury vapor (Schroeder and Munthe, 1998; Schroeder et al., 2003). It may also be bound to airborne particles that can be widely transported from the source of emission (U.S.E.P.A., 1997b). Mercury may be deposited into surface waters and lands. Most of the mercury in waters, soils, sediments, or plants and animals is in the form of inorganic mercury salts and organic forms of mercury. However, methylmercury has been found to be the predominant form of mercury in the 
tissues of fish caught in water containing predominantly inorganic mercury (Cai, 2000; Mason et al., 2005; Mason and Benoit, 2003; Mason et al., 1999; Monsalud, 1999). Therefore a chemical transformation of inorganic mercury $\left(\mathrm{Hg}^{2+}\right)$ to methylmercury $\left(\mathrm{CH}_{3} \mathrm{Hg}^{+}\right)$occurs in the natural environment (Gilmour et al., 2006; Gilmour and Henry, 1991; Gilmour et al., 1992; Gilmour et al., 1998; Mason et al., 2005; Mason and Benoit, 2003). Methylation of mercury has been shown to involve both biotic and abiotic pathways (Jensen and Jernel Ö.V, 1969; Nagase H.; Ose, 1982; Weber, 1993; Wood J.M. et al., 1969). By highly efficient bioaccumulation and biomagnification, neurotoxic methylmercury would eventually reach our food chain especially from seafood (NRC, 2000; Nriagu, 1993; Nuzzi, 1972; Topping and Davies, 1981). The USEPA conducted a quantitative human health risk assessment of methylmercury (U.S.E.P.A., 1997e1997f1997h). The assessment estimated that between 1-3\% of women of childbearing age in the US eat sufficient amounts of fish for their fetuses to be at risk from methylmercury exposure. The EPA's reference dose for methylmercury of $0.1 \mu \mathrm{g}$ per $\mathrm{g}$ of body weight per day is viewed as a scientifically justifiable level (NRC, 2000) for protecting human health from the adverse effects of methylmercury.

1.2 Sources of mercury in the environment

Natural mercury emissions include volcanoes, natural mercury deposits and volatilization from the ocean (Liu et al., 2008a; Liu et al., 2008b; Munthe et al., 2003; Murphy et al., 2006; U.S.E.P.A., 1997c; U.S.G.S., 1998), which was estimated by Mason (Mason, 1994) as 2000 tons per year. Naturally mercury-enriched material found associated with plate tectonic boundaries, areas of high crustal heat flow, precious and 
base metal mineralization, recent volcanism, and organic rich sedimentary rocks (Rasmussen, 1994). Large areas of land in the western United States are enriched in mercury, and mercury deposits are abundant (Jonasson and Boyle, 1972). However, since the $19^{\text {th }}$ century the total amount of mercury in the environment has grown by a factor of 2 to 5 above pre-industrial levels (Mason, 1994). Mercury was widely used in industry because of its diverse properties (U.S.E.P.A., 1997c1997i; U.S.G.S., 1998). As a consequence, it is clear that industry was an important source of mercury in the environment. Human activities are primarily responsible for mercury pollution, mainly from combustion and waste incineration (Porcella et al., 1997) from scrubber water or coal cleaning water produced by coal fired power plants and solid waste incinerators (Carroll and Truman, 1995; U.S.E.P.A., 1997c). The intentional use of mercury in products (i.e., batteries, paints, pesticides) in the US has decreased significantly in the past 20 years (U.S.D.O.I., 1994).

Elevated levels of mercury in waters remote from anthropogenic emission sources have also been documented (Rasmussen, 1994; Sorensen et al., 1994; Swain, 1992; U.S.E.P.A., 1997g, 1998; Uchino et al., 1987). This mercury levels indicate that atmospheric deposition is an important source of contamination. This situation raises concerns about increasing amounts of mercury in the global pool and the implications of mercury emissions and their impacts on both people and ecosystems worldwide. In December 2000, the EPA announced its intention to regulate mercury emissions from fossil fuel electric power plants under the Clean Air Act (Environmental Reporter, 2000). In addition to air emissions, mercury is also released in other ways, including waterborne discharges and direct disposal to the land (U.S.E.P.A., 1997c1997e). 
Over the years, some mercury compounds have been specifically developed as pesticides, fungicides, and germicides to be used on grains, in paints, and with vaccines (U.S.E.P.A., 2000). The examples of the usage of organomercury compounds include methylmercury and ethylmercury and phenylmercury as a fungicide and cereal seed treatment; thiomersal and mercurochrome as antiseptics; mersalyl, chlormerodrin, mercurophen and mercurophylline as diuretics. Although some of these compounds are not used any longer, their removal is not uniform throughout the world: ranging from outright bans, to recommendations and voluntary codes (Craig, 1986; U.S.D.O.I., 1994; U.S.E.P.A., 1997a).

\subsection{Biogeochemical cycling of mercury}

Once released into the environment, mercury is subject to a variety of processes and interactions. Environmental mercury is thought to move through various environmental compartments, possibly changing forms and species during this process. Like other elements, these processes are conceptualized as a cycle (Liu et al., 2008a; Liu et al., 2008b; Stober et al., 2001; Stordal et al., 1996; Tseng et al., 2004; Turner et al., 2001). Figure 1.1 illustrates mercury release by both natural and anthropogenic sources into environmental media: air, soil and water. When airborne mercury is deposited on land or in water, biological transformations can occur that converts some of the mercury to methylmercury. The amount of mercury transformed to methylmercury varies from one water body to another. 


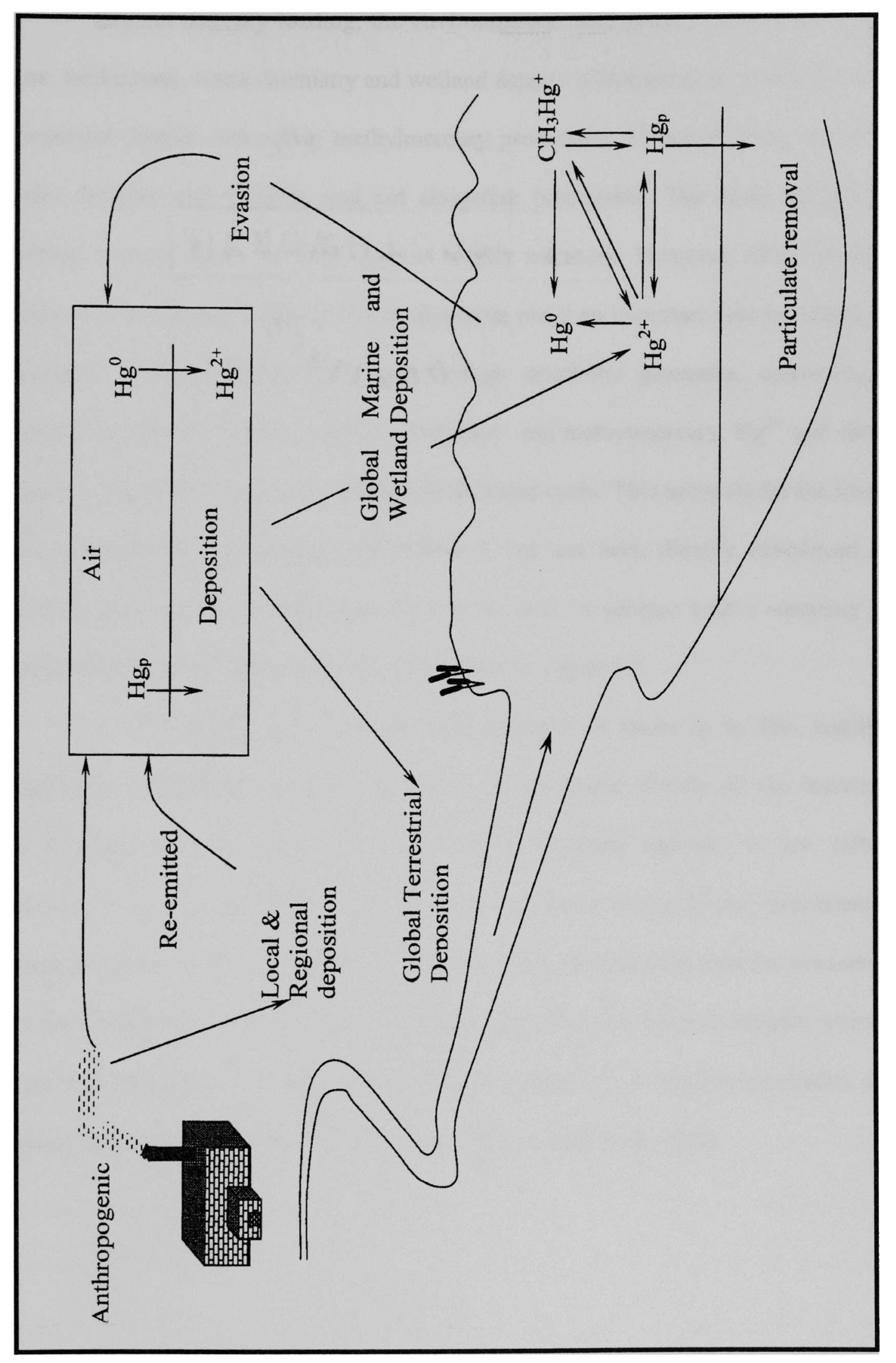

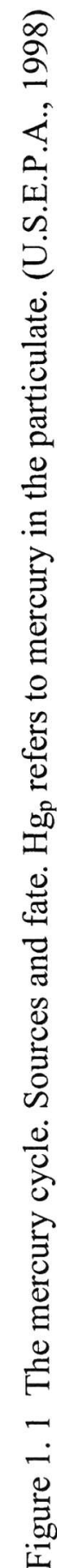


Beyond mercury loading, the environmental setting (i.e., climate, geology, land use, land cover), water chemistry and wetland density (Cleckner et al., 1999) are the most important factors controlling methylmercury production. However, these factors seem very complex and variable, and not altogether predictable. The exact mechanism by which mercury enters the food chain is largely unknown. However, EPA reported that bacteria that process sulfate in the environment plays an important role by taking up the mercury in its inorganic form and through metabolic processes, converting it to methylmercury (U.S.E.P.A., 1997b). Dimethyl- and methylmercury, $\mathrm{Hg}^{2+}$ and elemental mercury may interchange in a general biochemical cycle. This accounts for the formation of methylmercury in remote areas where it has not been directly introduced to the environment, but where $\mathrm{Hg}^{2+}$ may have been used. A scheme with a summary of the biogeochemical cycling of mercury is presented in Figure 1.2.

In lakes, rivers and reservoirs methylmercury is taken up by fish, resulting in significant methylmercury bioaccumulation in fish tissue. Nearly all the mercury that accumulates in fish tissue is methylmercury. Inorganic mercury is less efficiently absorbed and eliminated to a higher extent. In some instances the concentration of methylmercury in fish may be several orders of magnitude greater than the concentrations in the surrounding water or sediment. Research in mercury transport, transformations and fate will improve our understanding of the complexity of mercury processes once it enters the environment, and allow improved future regulatory efforts. 


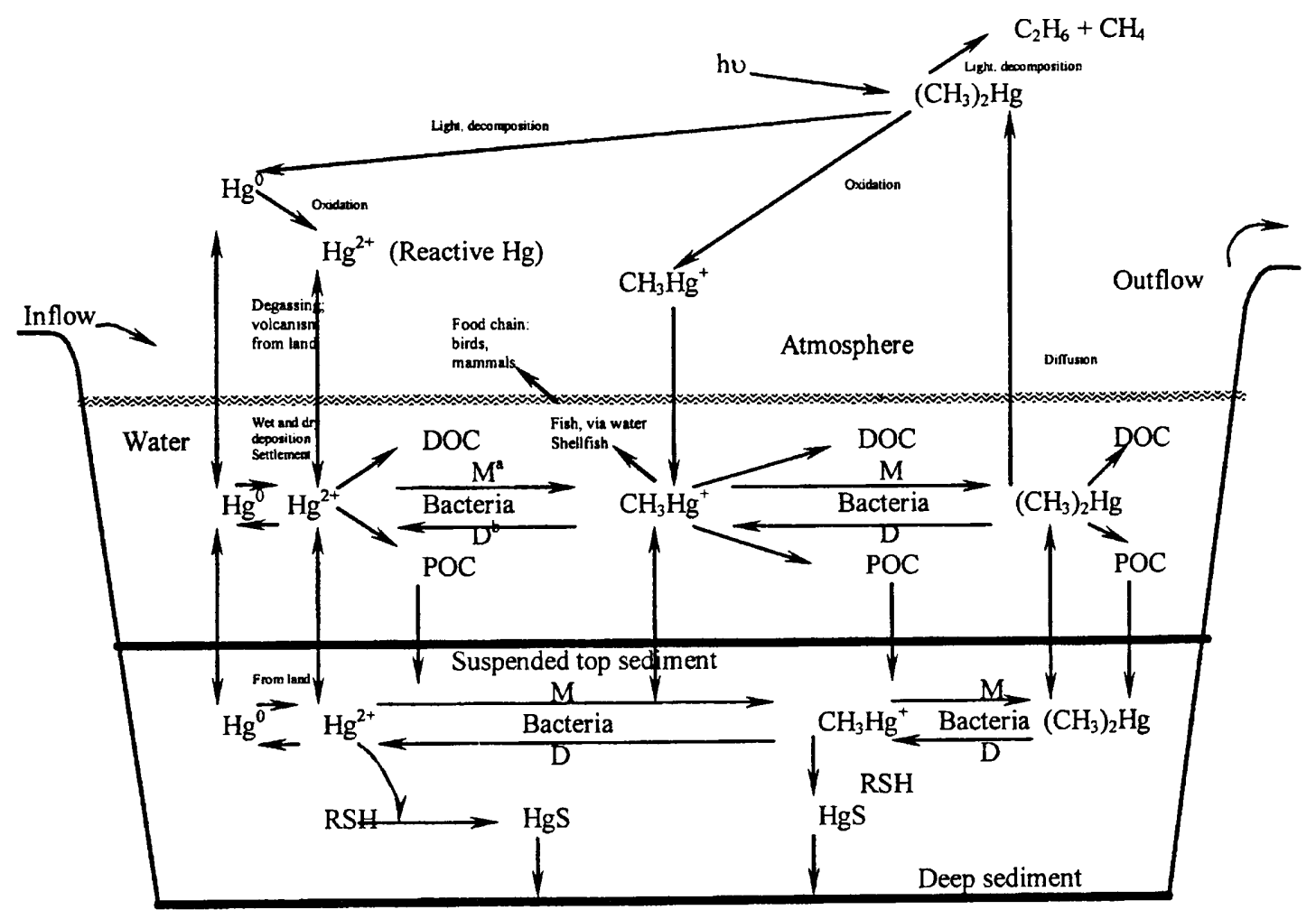

Figure 1. 2 Diagram summarizing the biogeochemical cycling of mercury in aquatic environments. $\mathrm{M}^{\mathrm{a}}=$ methylation (oxidative); $\mathrm{D}^{\mathrm{b}}=$ demethylation (bacterial reduction).

\section{$1.4 \quad$ Mercury in soil}

Mercury deposited in soils undergoes different chemical and biological transformations, such as $\mathrm{Hg}^{(0)}$ oxidation, and $\mathrm{Hg}^{2+}$ reduction or methylation depending on soil $\mathrm{pH}$, temperature and humic content. Inorganic forms of mercury in soils are quite soluble and therefore are highly mobile. However, $\mathrm{Hg}$ mobilization in soils through 
inorganic compounds such as $\mathrm{HgCl}_{2}$ and $\mathrm{Hg}(\mathrm{OH})_{2}$ is minor compared to mercury bound to soil humic substances. The formation of organic $\mathrm{Hg}^{2+}$ complexes is the dominating process due to the affinity of $\mathrm{Hg}^{2+}$ and its inorganic compound to sulfur containing functional groups. This tendency to complex limits the mobility of mercury in soil as most of the mercury is fixed in the bulk organic matter and can only be mobilized through elution in run off by being attached to suspended soil or humus. However, $\mathrm{Hg}^{2+}$ will be absorbed on soluble organic soil components such as fulvic acids and may be transferred to run off in the dissolved phase (U.S.E.P.A., 1997d, 2000). In a study done on the binding and mobility of mercury in soils contaminated by emissions from chloralkali plants (H. Bisester et al 2002), the highest mercury concentrations were found in the uppermost soil layer $(5 \mathrm{~cm})$. Mercury concentrations are proportional to a decrease in depth which in turn correlates with a decrease in organic matter content. Mercury is transported to deeper soil layers as soluble organic complexes. In sandy soils deficient in organic matter, coupling to humic substance is minor. Leachable $\mathrm{Hg}$ is in the form of soluble organic $\mathrm{Hg}$ complexes and is highest in soils with a high organic matter and low clay content. Reactive $\mathrm{Hg}$ or weak $\mathrm{Hg}$ complexes are retained in the uppermost soil layer through sorption on mineral surfaces. The size of the soil particle is also important when it binds to mercury. The content of mercury and organic matter decreases with particle size. Mercury was demonstrated in a study that mercury concentration in soil was high in fine particles, and that at $\mathrm{pH}$ of less than $2, \mathrm{Hg}^{2+}$ was the predominant species. (Wasay et al 1995). 


\subsection{Mercury problems in Oak Ridge Reservation}

Between 1950 and 1963, the DOE Y-12 Weapons Plant used mercury as part of the lithium isotope separation and purification process. Estimates of 330 metric tons of mercury were released into the environment; of that total, 110 metric tons were lost to the East Fork Poplar Creek (EFPC) (D.O.E, 1997). The study concluded that DOE could not account for an additional 750 metric tons of mercury used during that period . Releases of mercury to the creek contaminated instream sediments, and periodic flooding contaminated floodplain soils along the creek. The floodplain width ranges from 5 to 500 meters (D.O.E, 1983). Much of the mercury is now sequestered in the Y-12 plant.

In 1983, massive mercury contamination from the Y-12 Plant was discovered in East Fork Poplar Creek, which flows through residential areas of Oak Ridge. Seeing the impacts DOE had on the region, the State of Tennessee asserted its authority over activities on the Oak Ridge Reservation (ORR). This authority included enforcement of regulations, monitoring of the environment and oversight of cleanup on the ORR. During the past 15 years the Department of Energy has been identifying and remediating the sources of mercury in and near the Upper East Fork Poplar Creek (UEFPC) at the Y-12 plant.

Physical, chemical, and biological processes in the environment have altered some of the mercury into a variety of other organic and inorganic forms. The total mercury concentrations in the area are relatively known to be high. However, little is known about the fate, transport, and potential environmental impact of the high level mercury present in the soil and sediments in some area at the Oak Ridge Reservation. 


\subsection{Research Objectives}

The purpose of the research is to investigate the mercury speciation and to evaluate the mobility and bioavailability of mercury in the soil and sediment in the contaminated areas of Oak Ridge Reservation and to determine the factors that controls the fate, transport, and bioavailability of mercury in the ecosystem. The characterization of mercury in soil collected from this area will be conducted using sequential extractions and thermal desorption procedures. In order to obtain an overall assessment of mercury contamination in the Oak Ridge Reservation, efforts were also made to identify the different mercury species present in the soil, sediment and water surrounding the Y-12 area at Oak Ridge.

The significance of this study is that it will describe the behavior of mercury in the soil and how this behavior affects its potential impact to human health in the surrounding area. It will also lead to a better understanding of the mercury mobility in the environment, and this will directly affect the selection of the techniques used for mercury remediation in the future. 


\section{Chapter 2 Mercury speciation in Oak Ridge Reservation Soil.}

\section{$2.1 \quad$ Introduction}

Speciation analysis of mercury $(\mathrm{Hg})$ is important in assessing the risk posed by contaminated soils. This is because the fate, transport, and bioavailability of $\mathrm{Hg}$ in soil are dependent upon the species in which it is present (Barnett and Harris, 1997; Wallschlager and Desai, 1998; Wallschlager et al., 1998a). The speciation of $\mathrm{Hg}$ in soil and sediment may be defined functionally (e.g., bioavailable fraction) or operationally (e.g., water soluble, exchangeable, and organo-chelated $\mathrm{Hg}$ fractions). Mercury speciation can also be described to distinguish between specific chemical species (e.g. inorganic $\mathrm{Hg}$ and methylmercury) (Bloom et al., 2003). The procedures determining functionally or operationally defined $\mathrm{Hg}$ species are sometimes called fractionation rather than speciation (Martin-Doimeadios et al., 2000).

Sequential extraction procedures (SEP), thermal desorption analysis, and spectroscopic techniques are three major approaches to determine $\mathrm{Hg}$ speciation in soil. Sequential extraction, a widely used method for $\mathrm{Hg}$ speciation, can provide useful information related to environmental behavior of $\mathrm{Hg}$ in soil, such as solubility, mobility, and bioavailability (Biester and Scholz, 1997a; Han et al., 2003). Thermal desorption analysis has also been used for $\mathrm{Hg}$ species in solid samples. It offers the advantages of being simple, fast, and cost-effective (Bombach et al., 1994). Spectroscopic techniques, such as X-ray absorption fine structure spectroscopy or X-ray microprobe spectroscopy, can provide a direct observation of $\mathrm{Hg}$ speciation. The application of this approach, however, is limited by its relatively poor detection limit (Kim et al., 2003; Kim et al., 
2000). Combinations of these techniques rather than a single method are often needed to estimate $\mathrm{Hg}$ speciation and assess the environmental impact of $\mathrm{Hg}$ contaminated sites.

The Oak Ridge Reservation (ORR), especially in the area surrounding the Y-12 Weapons Complex, was heavily contaminated with Hg. In the 1950s and 1960s, an estimation of $108,000-212,000 \mathrm{~kg}$ of $\mathrm{Hg}$ was released to the headwaters of the East Fork Poplar Creek (EFPC) during the production of Lithium enriched in ${ }^{6} \mathrm{Li}$ in the Y-12 Plant, which resulted in a heavy $\mathrm{Hg}$ contamination in the floodplains of the EFPC. Efforts have been made to investigate the magnitude, speciation, mobility, and bioavailability of $\mathrm{Hg}$ in this area, especially the Lower EFPC (LEFPC) floodplains. The EFPC floodplain soils were found to contain $\mathrm{Hg}$ in concentration up to $3,000 \mu \mathrm{g} / \mathrm{g}$ and in a combination of various physicochemical forms such as $\mathrm{Hg}^{0}$, dissolved ionic $\mathrm{Hg}$, fine $\mathrm{Hg}$ particles attached to suspended matter, mercuric oxide, $\mathrm{Hg}$ covalently bound to organic matter, and mercuric sulfide (Barnett and Harris, 1995, 1997; Campbell et al., 1998; Han et al., 2009; Hollerman et al., 1999). Among these $\mathrm{Hg}$ forms, mercuric sulfide ( $\sim 85 \%$ of total $\mathrm{Hg}$ ) had been suggested as the predominant form (Revis and Osborne, 1989), but it was also detected in variable and sometimes relatively lower quantities (Barnett and Harris, 1995). Because of the severe contamination of $\mathrm{Hg}$, this site was placed on the National Priority List to undergo remediation (Barnett and Harris, 1997; Morris, 1995).

Despite extensive studies focusing $\mathrm{Hg}$ contamination in the LEFPC floodplains, it is currently not very clear about the magnitude and speciation of $\mathrm{Hg}$ present in soils coming from the DOE Y-12 site. The present study was carried out on a soil sample collected just outside the Y-12 boundary of the ORR site. The choice of this site for sample collection was based upon several technical bases. First of all it was the first 
easily accessible location beyond the $\mathrm{Y}-12$ property and would still have primarily the fingerprint of any Y-12 manipulations, e.g., fresh addition of Clinch River water for flow management. Secondly, samples taken from this site would have the least exposure to any of the downstream environmental influences, e.g., residual floodplain deposition or $\mathrm{Hg}$ reintroduction that might alter the original $\mathrm{Hg}$ transport from the $\mathrm{Y}-12$ site. And finally, various engineering activities on the Y-12 site over the years and near this sampling site, e.g., placement of rip-rap in the creek to reduce the transport of fine particulate, has lead to a different legacy of $\mathrm{Hg}$ contamination at this site than from say the LEFPC floodplains.

A prominent redoximorphic characteristic of soil was observed throughout area surrounding the Y-12 site, i.e., the soil was clearly composed of two components: a gray part (termed as redoximorphic depletions) and a brownish part (termed as redoximorphic concentrations) (Fig. 2.1). The concentration, phase association, mobility, and volatility of $\mathrm{Hg}$ present in these two components were inferred to be different based on the previous observation that fairly different $\mathrm{Hg}$ concentrations were present in these two components. The effect of soil redoximorphic features on $\mathrm{Hg}$ concentration and phase association has not been investigated in previous studies dealing with $\mathrm{Hg}$ speciation. Most of them applied operationally defined speciation techniques (SEP and/or thermal desorption) to bulk soil samples (wet or dried) (Biester et al., 2000; Biester and Scholz, 1997b; Bloom et al., 2003). In the present study, I make a new attempt to characterize $\mathrm{Hg}$ speciation and to evaluate $\mathrm{Hg}$ mobility in soils. I first fractionated the soil sample based on redox induced alteration of soil characteristics. Then, I applied SEP and thermal desorption analysis to the fractionated soil components rather than bulk soil sample. The 
objective of this study is to provide a typical example for expanding and detailing the methodology characterizing $\mathrm{Hg}$ speciation in soil by applying multiple speciation techniques coupled with fractionation methods. I selected only a typical sample based on the results of previous survey of $\mathrm{Hg}$ contamination in the studied area. However, the data generated from various analytical protocols applied in the present study should be potentially useful for investigating the phase association and environmental risk of $\mathrm{Hg}$ probably influenced by soil features in the concerned area.

\section{$2.2 \quad$ Experimental}

\subsubsection{Soil sample collection}

The soil sample was taken from the EFPC banks at levels $4-8$ inches above the water surface using a garden trowel just outside the Y-12 Complex site boundary in Oak Ridge. The sampling site was located approximately a quarter mile offsite, beyond the cement culvert that conveys the stream from the $\mathrm{Y}-12$ site, and directly behind a commercial car wash (Mullins Car Wash). The sample was shipped to FIU on dry ice and stored at $-20^{\circ} \mathrm{C}$ before being analyzed for $\mathrm{Hg}$ and $\mathrm{Hg}$ speciation.

\subsubsection{Fractionation of soil sample}

To determine whether $\mathrm{Hg}$ concentration and speciation in the soil sample were affected by soil composition, the redoximorphic depletions and concentrations were manually separated. In the low-chroma gray redoximorphic depletions part (Fig. 2.1), Fe and $\mathrm{Mn}$ oxide or a combination of $\mathrm{Fe}$ and $\mathrm{Mn}$ oxide and clay appeared to have been 
partially removed via redox processes related to seasonal saturation. The brownish redoximorphic concentrations part seemed to contain more $\mathrm{Fe}$ and $\mathrm{Mn}$ oxide. The analysis for major elements in these two components confirmed that redoximorphic concentrations contained higher concentrations of $\mathrm{Fe}, \mathrm{Mn}, \mathrm{Ca}$, and $\mathrm{Mg}$ than redoximorphic depletions. The mass amount of redoximorphic concentrations was much larger than redoximorphic depletions as observed during separation process of these two components. Although these two components were not separated completely in the laboratory, differences in $\mathrm{Hg}$ concentration and association with soil caused by these two components, if any, should be observed.

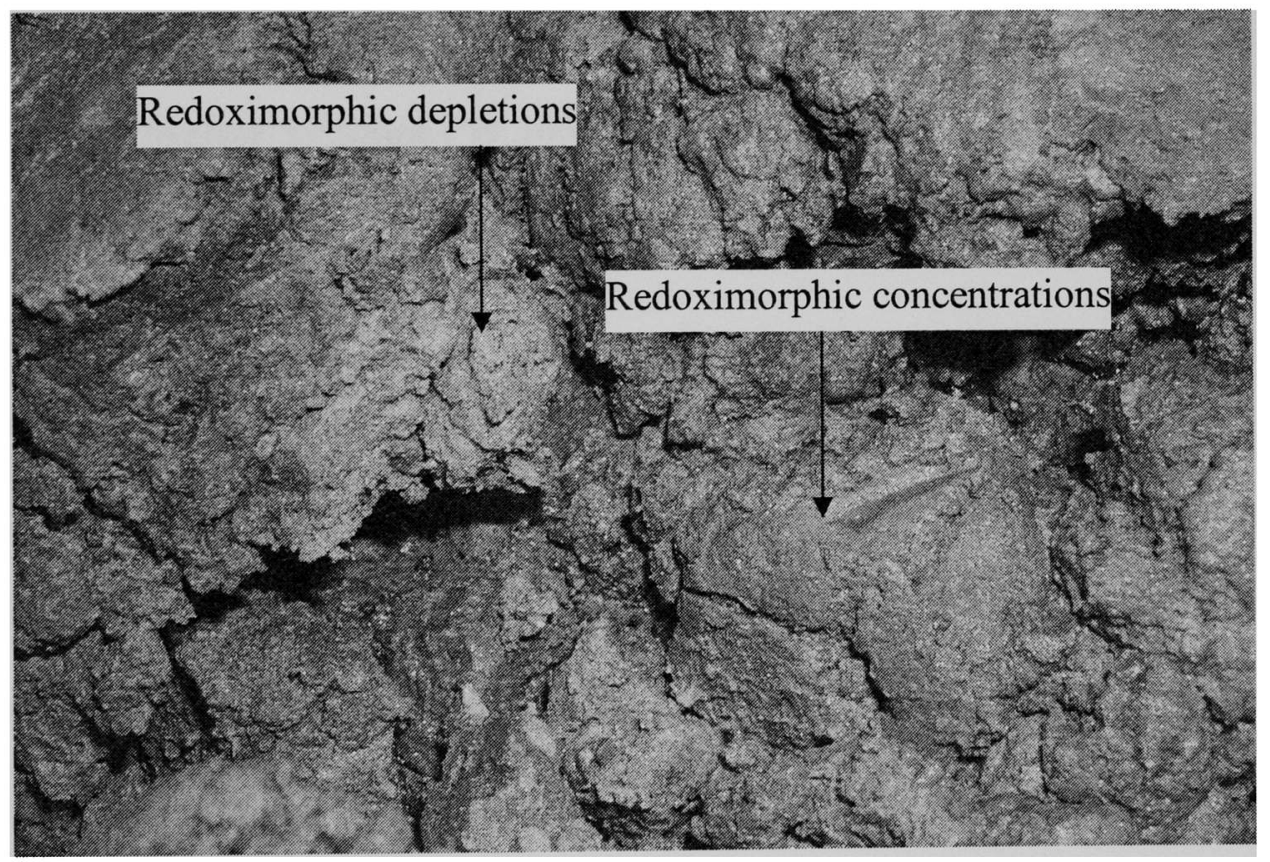

Figure 2. 1 Redoximorphic depletions (gray color) and redoximorphic concentrations (brown color) in Y-12 soil sample 
Part of the two separated components was stored in a freezer and another part was freeze-dried for $72 \mathrm{~h}$. The dried samples were then grinded with a mortar and separated into fine and coarse particle fractions in order to investigate the effect of particle size on $\mathrm{Hg}$ distribution. Number 35 and Number 60 sieves were used to separate coarse particles $(<500 \mu \mathrm{m})$ and fine particles $(<250 \mu \mathrm{m})$, respectively.

Contents of major elements ( $\mathrm{Al}, \mathrm{Mg}, \mathrm{Ca}, \mathrm{Mn}, \mathrm{Fe})$ in the fractionated samples were determined by inductively coupled plasma mass spectrometry (ICPMS) ( $\mathrm{Mg}, \mathrm{Ca}$, $\mathrm{Mn}$ ) or atomic absorption spectrometry (AAS) (Al and $\mathrm{Fe}$ ) following $\mathrm{HNO}_{3} / \mathrm{H}_{2} \mathrm{O}_{2}$ digestion (Cai et al., 2002). Organic carbon contents in these samples were determined by subtracting inorganic carbon content from total carbon content. Clay speciation and mineral identification were also conducted on the four fractionated subsamples using $\mathrm{X}$ ray diffraction analysis (Phillips PW 1050 diffractometer) at Activation Laboratories Ltd. (Ontario, Canada).

\subsubsection{Reagents and instrumentation}

A cold vapor atomic fluorescence spectrometer (CVAFS) system (Merlin10.035, PS Analytical, UK) was used for Hg analysis. A Gyrotory shaker (model G2) from New Brunswick Scientific Co., Inc. (Edison, NJ) and a Blue M oven (Blue Island, IL) were used for sequential extraction and thermal desorption. A certified $\mathrm{Hg}$ standard (1000 ppm in $1.8 \% \mathrm{HNO}_{3}$ ) was purchased from Fischer Scientific (Fair Lawn, NJ). Another certified $\mathrm{Hg}$ standard (1000 ppm in $10 \% \mathrm{HNO}_{3}$ ) from second source (SPEX CertiPrep, Metuchen, NJ) was used for calibration check. A river sediment standard reference material (SRM) NIST 8406 , with nominal values of $60 \mathrm{ng} / \mathrm{g}$ for $\mathrm{Hg}$ and $5.50 \%$ for $\mathrm{Al}, 2.96 \%$ for $\mathrm{Fe}$, and 
$0.043 \%$ for Mn, was purchased from the National Institute of Standard and Technology (Gaithersburg, MD). Trace metal grade of $\mathrm{HCl}$ and $\mathrm{HNO}_{3}$, analytical grade of potassium bromide, potassium bromate, stannous chloride, and other reagents were purchase from Fisher Scientific.

\subsubsection{Determination of $\mathrm{Hg}$ in fractionated samples}

Samples ( 0.1 to $0.3 \mathrm{~g}$ wet or dry) were placed inside a $10 \mathrm{ml}$ Wheaton glass ampoule to which $1 \mathrm{ml}$ of $\mathrm{H}_{2} \mathrm{O}$ and $2 \mathrm{ml}$ of concentrated $\mathrm{HNO}_{3}$ were added (Jones et al., 1995). The samples were allowed to settle for 20 minutes, then sealed using an Ampulmatic Ampule Sealer, and digested in an autoclave at $120^{\circ} \mathrm{C}$ for 1 hour. The samples were analyzed after cooling down. All results were calculated based on dry weight unless stated otherwise.

\subsubsection{Thermal desorption experiments}

Thermal desorption experiments were performed on NIST 8406 and on the wet and dry redoximorphic depletions and redoximorphic concentrations of the ORR soil sample without further differentiation into particle size. Soil samples ( 0.1 to $0.2 \mathrm{~g})$ were weighed into a $10 \mathrm{ml}$ Wheaton glass ampule. The thermal desorption experiments were performed at temperatures ranging from 60 to $180^{\circ} \mathrm{C}$ for a period of 15 hours inside an oven. The glass ampules were then removed from the oven and allowed to cool. The concentration of $\mathrm{Hg}$ remained in the samples were determined using $\mathrm{HNO}_{3}$ digestionCVAFS procedure as described above. Triplicates of the sample and three blanks were carried out for each temperature. Each ampule was analyzed three times. 


\subsubsection{Sequential extraction procedure}

A sequential extraction procedure reported previously by Bloom et al. (2003) was conducted on the fine and coarse freeze-dried redoximorphic depletions and redoximorphic concentrations (Fig. 2.2). Listed in Table 2.1 are definitions of the five different fractions and the correspondent extractant used in each step. An aliquot of approximately $0.4 \mathrm{~g}$ of sample was used in the sequential extraction. For each step, $40 \mathrm{ml}$ of extractant was added except for step 5 in which $13 \mathrm{ml}$ of aqua regia was used. The extraction was conducted by shaking on an orbital shaker at $200 \mathrm{rpm}$ at room temperature for 24 hours. After centrifuging at $3000 \mathrm{rpm}$ for 5 minutes, the supernatant was carefully decanted into a $250 \mathrm{ml}$ plastic bottle and the precipitate was rinsed with $40 \mathrm{ml}$ of the same corresponding extractant by shaking vigorously and followed by centrifugation. The two supernatant solutions were then combined. The concentration of $\mathrm{Hg}$ in the supernatants was determined by CVAFS according to the laboratory procedure (Jones et al., 1995).

Table 2.1 Extractants and $\mathrm{Hg}$ fractions used in the sequential extraction procedure.

Extractions were conducted at room temperature $\left(20^{\circ} \mathrm{C}\right)$ for 24 hours.

\begin{tabular}{llll}
\hline Fraction ID & Extractant & Extractant:soil ratio & $\mathrm{Hg}$ fraction \\
\hline F1 & deionized water & $100: 1$ & Water soluble $\mathrm{Hg}$ \\
F2 & $0.1 \mathrm{M} \mathrm{CH}_{3} \mathrm{COOH}+0.01 \mathrm{M} \mathrm{HCl}$ & $100: 1$ & human stomach acid soluble $\mathrm{Hg}$ \\
F3 & $1 \mathrm{M} \mathrm{KOH}$ & $100: 1$ & organic matter bound $\mathrm{Hg}$ \\
F4 & $12 \mathrm{M} \mathrm{HNO}_{3}$ & $100: 1$ & $\mathrm{Hg}^{0}$ \\
F5 & aqua regia & $32.5: 1$ & mercuric sulfide \\
\hline
\end{tabular}




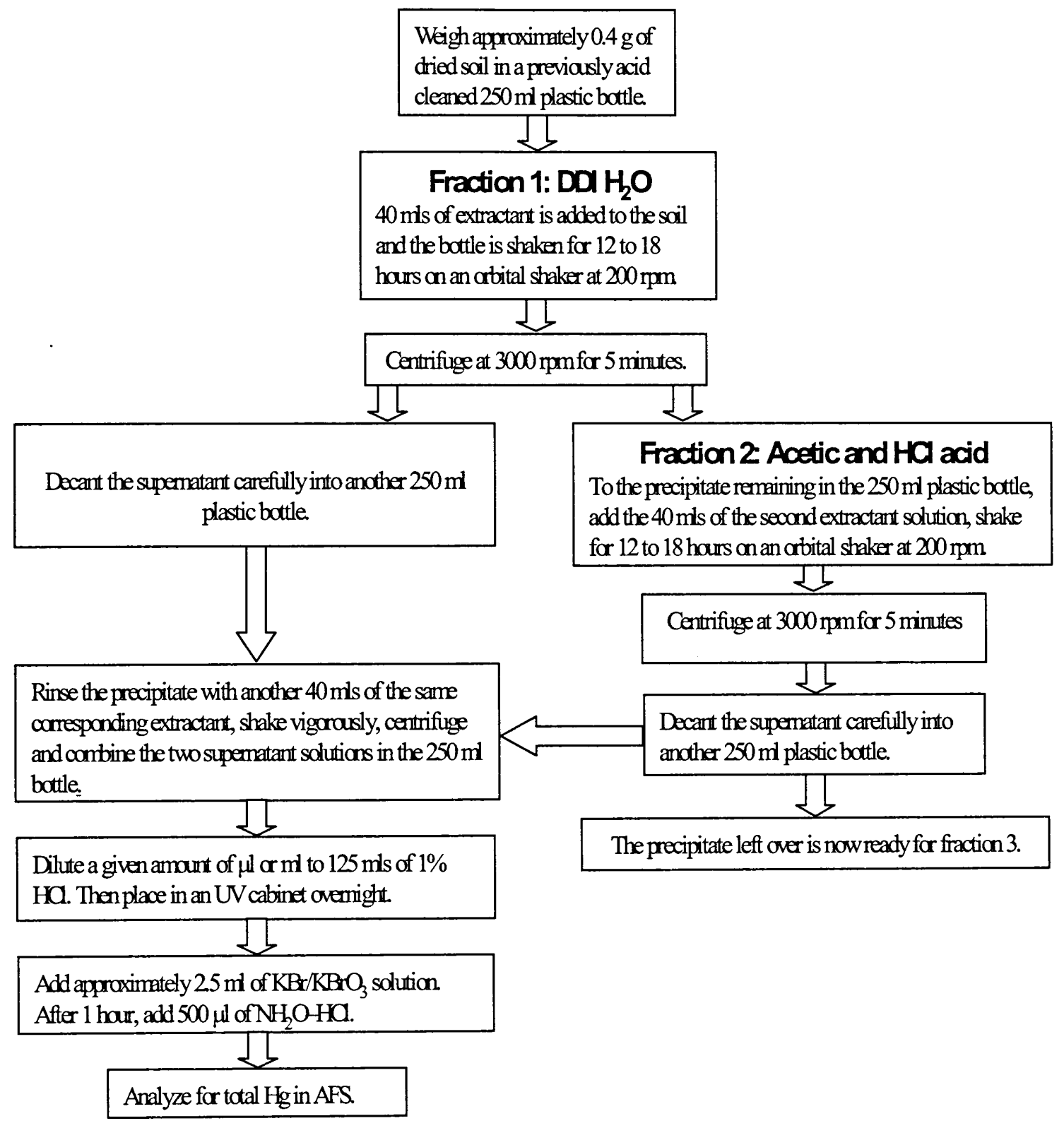

Figure. 2.2 A scheme showing the sequential extraction procedure used in this study. 

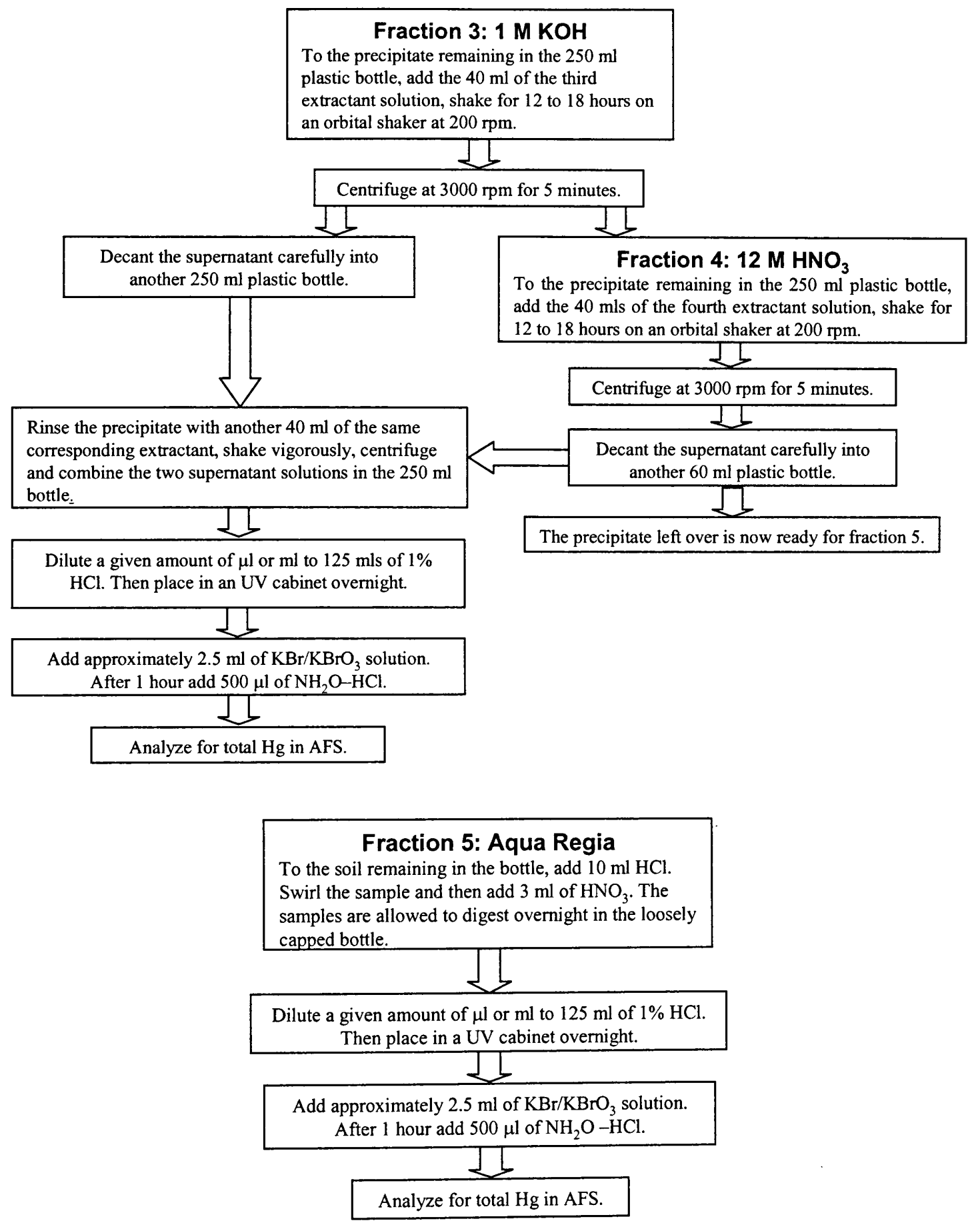

Fig. 2.2 (cont'd) A scheme showing the sequential extraction procedure used in this study 


\subsection{Results and Discussion}

\subsubsection{Soil characterization}

The results of X-ray minerals identification revealed a similar pattern for the manually separated redoximorphic depletions and redoximorphic concentrations, with quartz alpha, sericite, muscovite or mica, and orthoclase the major mineral forms. The Xray diffraction patterns of the clay speciation for these two components were also similar. However, differences in clay mineral compositions between redoximorphic depletions and redoximorphic concentrations were observed. Vermiculite and kaolinite/dickite or nacrite were present in both components, but interstratified vermiculite/illite was identified only in the redoximorphic concentrations. Additionally, two peaks at 10.09 and $4.96 \AA$ observed in the redoximorphic concentrations clearly indicate the presence of illite. Only one peak at $4.96 \AA$ was found in the redoximorphic depletions, which could not confirm the presence of illite because of the possible interferences of sericite or muscovite. It seemed that the redoximorphic concentrations contained more types of minerals containing $\mathrm{Fe} / \mathrm{Mg}$ than the redoximorphic depletions.

The concentrations of some major elements $(\mathrm{Al}, \mathrm{Mg}, \mathrm{Ca}, \mathrm{Mn}, \mathrm{Fe})$ in the redoximorphic depletions and redoximorphic concentrations were different as seen in Table 2.2. As expected, significantly higher concentrations of non-silica mineral elements such as $\mathrm{Mg}, \mathrm{Ca}$, especially $\mathrm{Mn}$ and $\mathrm{Fe}$, were observed for the redoximorphic concentrations compared with redoximorphic depletions. This seemed to be related to the presence of more types of $\mathrm{Fe} / \mathrm{Mg}$ minerals such as illite and interstratified vermiculite/illite in the redoximorphic concentrations. The organic carbon content in the redoximorphic concentrations was also higher than redoximorphic depletions. 
Table 2.2 Content of major elements and organic carbon in fractionated subsamples

\begin{tabular}{|c|c|c|c|c|c|c|c|c|}
\hline \multirow{2}{*}{ Subsample type } & & & \multicolumn{5}{|c|}{ Major elements (\%) } & \multirow{2}{*}{$\begin{array}{c}\text { Organic } \\
\text { carbon (\%) }\end{array}$} \\
\hline & & & $\mathrm{Al}$ & $\mathrm{Mg}$ & $\mathrm{Ca}$ & $\mathrm{Mn}$ & $\mathrm{Fe}$ & \\
\hline \multirow{5}{*}{ Redoximorphic depletions } & & mean & 0.25 & 0.08 & 0.08 & 0.01 & 0.98 & 0.08 \\
\hline & coarse & $\mathrm{SD}$ & 0.01 & 0.00 & 0.00 & 0.00 & 0.06 & 0.01 \\
\hline & & & & & & & & \\
\hline & & mean & 0.30 & 0.09 & 0.10 & 0.01 & 1.05 & 0.06 \\
\hline & & SD & 0.01 & 0.00 & 0.00 & 0.00 & 0.01 & 0.01 \\
\hline \multirow{5}{*}{ Redoximorphic concentrations } & & mean & 0.37 & 0.10 & 0.11 & 0.08 & 2.11 & 0.17 \\
\hline & coarse & SD & 001 & 000 & $0 \Omega 0$ & 001 & 004 & $\cap 01$ \\
\hline & & & & & & & & \\
\hline & & mean & 0.34 & 0.09 & 0.11 & 0.04 & 1.70 & 0.10 \\
\hline & & $\mathrm{SD}$ & 0.001 & 0.00 & 0.01 & 0.00 & 0.01 & 0.01 \\
\hline
\end{tabular}

2.3.2 $\mathrm{Hg}$ in the redoximorphic depletions and redoximorphic concentrations with different particle sizes

It was observed that loss of $\mathrm{Hg}$ occurred for the redoximorphic depletions during the freeze-drying process (Table 2.3). The concentration of $\mathrm{Hg}$ in wet redoximorphic depletions sample $(91.8 \pm 11.6 \mathrm{ng} / \mathrm{g})$ was significantly different $(\mathrm{P}<0.01)$ from that in the freeze-dried sample $(57.3 \pm 1.2 \mathrm{ng} / \mathrm{g})$. For the redoximorphic concentrations, there was no significant difference between $\mathrm{Hg}$ concentrations before and after freeze-drying (206.6 \pm 57.8 versus $235.9 \pm 7.8 \mathrm{ng} / \mathrm{g}$ ). The high standard deviations for the wet samples could be attributed to the lack of homogeneity of the sample used. As discussed in the following paragraph, the redoximorphic concentrations has stronger binding affinity to $\mathrm{Hg}$ resulted from higher $\mathrm{Fe} / \mathrm{Mn}$ and organic carbon contents than redoximorphic depletions. This appeared to be partially responsible for the difference of $\mathrm{Hg}$ loss during 
the freeze-drying process between redoximorphic depletions and redoximorphic concentrations.

Table 2.3 Hg concentrations in the redoximorphic depletions and redoximorphic concentrations from the ORR soil sample with different particle size

\begin{tabular}{ccccccccc}
\hline & \multicolumn{3}{c}{ Redoximorphic depletions } & \multicolumn{7}{c}{ Redoximorphic concentrations } \\
\hline & Wet & Dry & Fine & Coarse & Wet & Dry & Fine & Coarse \\
Hg concentration (ng/g) & 91.8 & 57.3 & 76.7 & 50.5 & 206.6 & 235.9 & 203.2 & 121.9 \\
SD & 11.6 & 1.2 & 3.8 & 5.7 & 57.8 & 7.8 & 13.7 & 22.9 \\
\hline
\end{tabular}

$\mathrm{Hg}$ concentrations in the redoximorphic concentrations were significantly higher than in the redoximorphic depletions $(\mathrm{P}<0.01)$ (Table 2.3). The $\mathrm{Hg}$ concentration in the fine redoximorphic concentrations $(203.2 \mathrm{ng} / \mathrm{g})$ was almost three-fold of the fine redoximorphic depletions $(76.7 \mathrm{ng} / \mathrm{g})$, whereas the $\mathrm{Hg}$ concentration in the coarse redoximorphic concentrations $(121.9 \mathrm{ng} / \mathrm{g})$ was twice as much as that in the coarse redoximorphic depletions $(50.5 \mathrm{ng} / \mathrm{g})$. This is not unexpected because the redoximorphic concentrations contained higher $\mathrm{Fe}$ and $\mathrm{Mn}$ than the redoximorphic depletions (Table 2.1). The minerals of $\mathrm{Fe}$ and $\mathrm{Mn}$ such as iron hydroxide and hydrated manganese oxides have been known to have high affinity to $\mathrm{Hg}$ (Andersson, 1979; Dudas, 1976). Organic matter present in soils could also strongly bind $\mathrm{Hg}$ (Andersson, 1979). It was observed that organic carbon was higher in the redoximorphic concentrations than the redoximorphic depletions for both fine and coarse particle sizes (Table 2.2). Although organic carbon content in the studied sample seems to be low $(0.06-0.17 \%)$, such an 
organic carbon content was likely high enough for combining an accountable portion of $\mathrm{Hg}$. This presumption was based on a previous observation that binding of $\mathrm{Hg}$ to organic carbon, the predominant process of $\mathrm{Hg}$ sorption in the studied soils, showed no correlation with soil organic carbon content (Biester et al., 2002b). It was reported that about $82.5 \%$ of total $\mathrm{Hg}$ was found as humic/fulvic acid-bound form in a soil sample with $0.28 \%$ of organic carbon content whereas only $21.8 \%$ was found in another soil sample with $0.69 \%$ of organic carbon content (Biester et al., 2002a).

Particle size had an apparent effect on $\mathrm{Hg}$ distribution in the soil sample. For both redoximorphic depletions and redoximorphic concentrations, fine particles contained higher concentration of $\mathrm{Hg}$ compared with coarse particles (Table 2.3). The difference in $\mathrm{Hg}$ concentration between coarse and fine fraction was statistically significant as confirmed by a $\mathrm{t}$-test $(\mathrm{P}<0.01)$. Apparently the specific surface area of fine particles was higher than that of coarse particles, which was likely the reason for higher $\mathrm{Hg}$ concentration in the fine fraction. It has often been observed that adsorption of $\mathrm{Hg}$ is increased with decreasing particle size and increasing specific surface area (Andersson, 1979).

\subsubsection{Thermal desorption experiments}

Illustrated in Fig 2.3 is the $\mathrm{Hg}$ concentration for wet and dry redoximorphic depletions and redoximorphic concentrations of the ORR soil sample and NIST 8406 after thermal treatment at different temperatures. The differences in $\mathrm{Hg}$ concentration between untreated and thermally treated samples indicated the amount of $\mathrm{Hg}$ released. As 
expected, thermal treatment released certain amounts of $\mathrm{Hg}$ and the amounts of $\mathrm{Hg}$ vaporized varied with sample types and temperatures.

Significant $\mathrm{Hg}$ release was observed only when treatment temperature was $140{ }^{\circ} \mathrm{C}$ or higher except for the wet redoximorphic depletions subsample. For this sample, significant $(\mathrm{P}=0.05)$ reduction in $\mathrm{Hg}$ concentration was not observed after thermal treatment from 80 to $180^{\circ} \mathrm{C}$, whereas an unexpected significant $(\mathrm{P}<0.05)$ increase in $\mathrm{Hg}$ concentration was observed for 80 and $120^{\circ} \mathrm{C}$ treatments. The reason for the increase in $\mathrm{Hg}$ is not very clear. However, it is plausible that the difficulty of obtaining a homogenized sample from the wet soil could cause the sample unrepresentative. As for the amount of $\mathrm{Hg}$ released, about $20-30 \%$ of total $\mathrm{Hg}$ was released from the freeze-dried samples after they were heated at $180{ }^{\circ} \mathrm{C}$ for 15 hours. The percentage of the released $\mathrm{Hg}$ was somewhat lower (10-25\%) from the wet redoximorphic concentrations through the same treatment. It was observed that placing wet soil in ampoules generated relatively large and dense soil particles after drying at high temperatures. The presence of these large particles was thought to affect the release of $\mathrm{Hg}$ under varying temperatures. Therefore, it is likely that $\mathrm{Hg}$ was released more from the freeze-dried compared to the wet soil samples when heated. Compared with the freeze-drying process, less loss of $\mathrm{Hg}$ was observed for the wet redoximorphic depletions during thermal desorption treatments. This could be attributed to the inhomogeneity of wet sample or formation of these large and dense particles. It was also noted that much more $\mathrm{Hg}(>50 \%)$ was released in NIST 8406 after $180^{\circ} \mathrm{C}$ treatment compared with the ORR soil sample possibly due to the differences of soil properties and $\mathrm{Hg}$ binding forms between them (Fig. 2.3). 

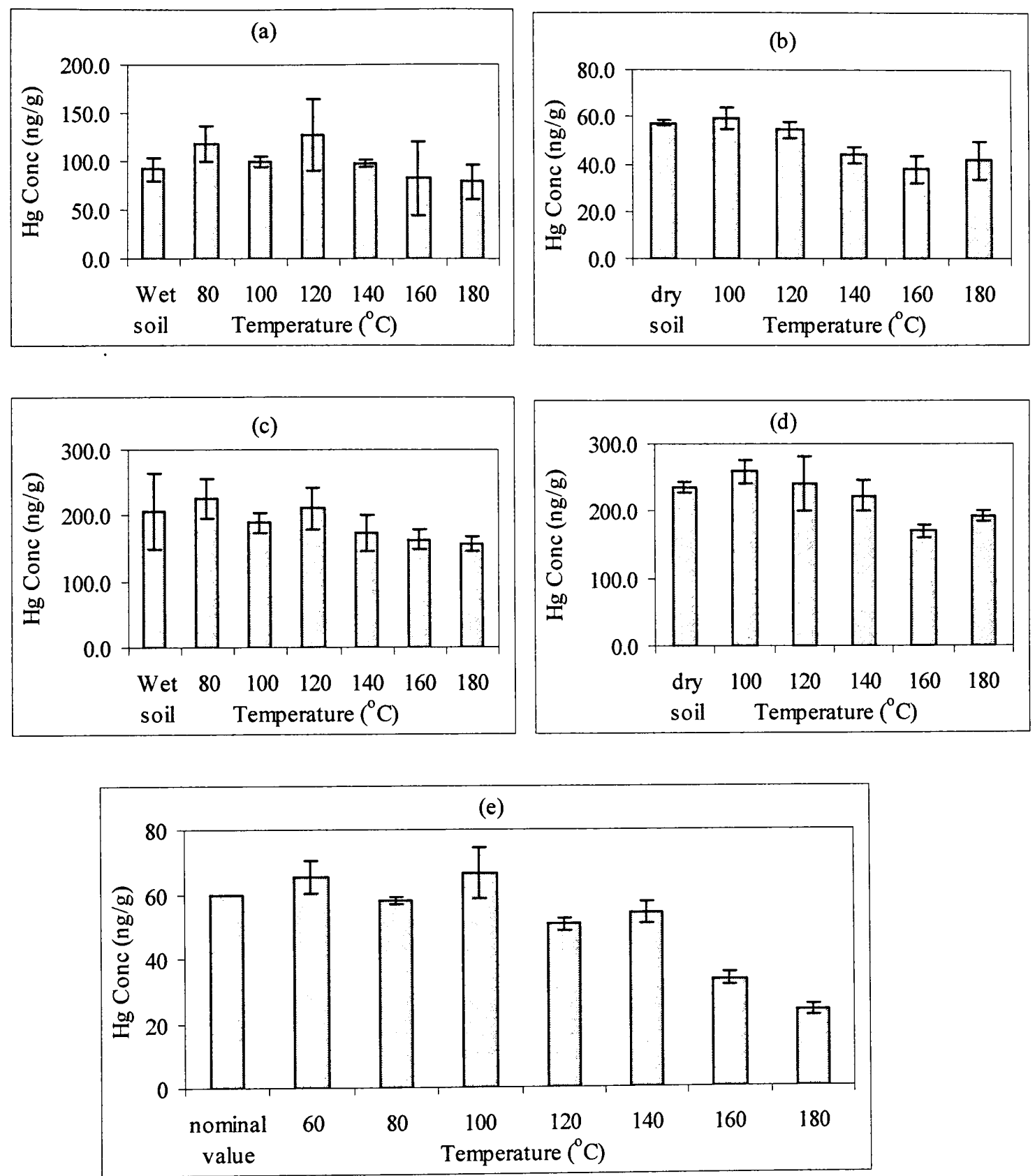

Fig. $2.3 \mathrm{Hg}$ concentration in the ORR soil sample and SRM NIST 8406 after thermal desorption treatments. (a) Wet redoximorphic depletions; (b) Freeze-dried redoximorphic depletions; (c) Wet redoximorphic concentrations; (d) Freezedried redoximorphic concentrations; (e) NIST 8406 
Since different $\mathrm{Hg}$ species present in solid samples are expected to be released at different temperatures (Bombach et al., 1994; Windmöller et al., 1996), thermal desorption may provide some information on $\mathrm{Hg}$ species present in soils. It has been reported that $\mathrm{Hg}^{0}, \mathrm{Hg}_{2} \mathrm{Cl}_{2}, \mathrm{HgCl}_{2}, \mathrm{HgS}$, and $\mathrm{Hg}$ associated with organic matter could be released at $<150,170,220-250,300-400$, and $200-300{ }^{\circ} \mathrm{C}$, respectively (Biester et al., 2000; Bombach et al., 1994; Windmöller et al., 1996). Therefore, it can be assumed that thermal desorption with temperature lower than $180{ }^{\circ} \mathrm{C}$ adopted in the present study would primarily release $\mathrm{Hg}^{0}$ and $\mathrm{Hg}_{2} \mathrm{Cl}_{2}$, and probably a small portion of other forms of $\mathrm{Hg}$ such as $\mathrm{HgCl}_{2}, \mathrm{Hg}\left(\mathrm{NO}_{3}\right)_{2}, \mathrm{HgO}$ (Windmöller et al., 1996). It is estimated that $\mathrm{Hg}^{0}$ and/or other "easily" vaporized $\mathrm{Hg}$ species appeared to account for 10-30\% of $\mathrm{Hg}$ species in the soil studied. Although large amount of $\mathrm{Hg}^{0}$ was initially discharged to the environments in the studied area (Barnett and Harris, 1997), it may have been converted to other $\mathrm{Hg}$ species during discharge or aging processes in the complex environments. In addition, lack of significant $\mathrm{Hg}$ release at less than $120{ }^{\circ} \mathrm{C}$ indicated that the $\mathrm{Hg}$ in this soil was relatively thermal stable and would not be thermally released under real-world environmental conditions. Temperature higher than $180^{\circ} \mathrm{C}$ was not tested in the present study because this study was designed to investigate $\mathrm{Hg}$ species with high mobility or volatility simulating the real environment.

Mercury retained in different soil mineral fractions was believed to have different mobility potential because of difference in texture of soil fractions (Andersson, 1979). It was observed that $\mathrm{Hg}$ retained in the redoximorphic concentrations had stronger interactions with the matrix and thus was more resistant to be mobile than $\mathrm{Hg}$ in the redoximorphic depletions for the ORR soil sample. An apparent $\mathrm{Hg}$ release occurred 
from $140{ }^{\circ} \mathrm{C}$ for the freeze-dried redoximorphic depletions whereas it did from $160{ }^{\circ} \mathrm{C}$ for the freeze-dried redoximorphic concentrations. Moreover, $30.7 \%$ of total $\mathrm{Hg}$ was released for the redoximorphic depletions at $180{ }^{\circ} \mathrm{C}$ while $18.1 \%$ was observed for the redoximorphic concentrations after the same treatment. This could be indicative of the fact that $\mathrm{Hg}$ retained in the redoximorphic concentrations was less volatile than $\mathrm{Hg}$ in redoximorphic depletions.

\subsubsection{Sequential extraction}

Mercury extracted in each step (F1-F5), representing different forms of $\mathrm{Hg}$ associated with different soil phases, is presented in Table 2.4. The sum of the amount removed by each extractant was in good agreement with the amount released by digestion with concentrated nitric acid with recoveries ranging from 94.3 to $125.1 \%$. In addition, a recovery of $68.8 \%$ for SRM NIST 8406 was achieved, suggesting higher residual $\mathrm{Hg}$ left after these five extraction steps.

The distribution of $\mathrm{Hg}$ in each fraction showed considerable similarities for all four subsamples of the ORR soil and SRM NIST 8406. Figure 2.4 shows the percentage of $\mathrm{Hg}$ extracted in each step calculated against the sum of $\mathrm{Hg}$ recovered in all five steps. In all cases the most abundant $\mathrm{Hg}$ fraction was organic matter bound $\mathrm{Hg}$ fraction $(\mathrm{F} 3)$ with percentage higher than $50 \%$ of total $\mathrm{Hg}$. The second highest fraction was F4 (20$30 \%$ ), representing $\mathrm{Hg}^{0}$ based on the fact that all free $\mathrm{Hg}^{0}$ present in a sample could be dissolved in the cold $12 \mathrm{M} \mathrm{HNO}_{3}$ (Bloom et al., 2003; Gerlach CL, 1995). It should be noted that some other classes of $\mathrm{Hg}$ compounds such as $\mathrm{Hg}(\mathrm{I}), \mathrm{Hg}$ associated with amorphous organo-sulfur, $\mathrm{Hg}-\mathrm{Ag}$ amalgams, and $\mathrm{Hg}$ associated with crystalline $\mathrm{Fe} / \mathrm{Mn}$ 
oxide phases may be extracted into F4 fraction. Besides F3 and F4, the aqua regia soluble $\mathrm{Hg}$ fraction, F5, operationally termed as mercuric sulfide ( $\mathrm{HgS})$ including both cinnabar and metacinnabar and mercuric selenide $(\mathrm{HgSe})$, also contributed an accountable portion to total $\mathrm{Hg}$ in the samples (about $10 \%$ ). The first two sequentially extracted fractions $\mathrm{F} 1$ and F2, representing water soluble and human stomach acid soluble $\mathrm{Hg}$, respectively, were relatively small portions.

These five $\mathrm{Hg}$ fractions have different mobility and potential bioavailability. The first two fractions (F1 and F2) were probably most important $\mathrm{Hg}$ classes in view of environmental concerns. Water soluble (F1) $\mathrm{Hg}$ fraction is likely the most labile and able to migrate in interstitial soil solutions (Kot et al., 2001), and even moves downward into deeper soil layer or groundwater. F2 fraction, simulating human stomach acid soluble $\mathrm{Hg}$ species, was determined as the fraction of $\mathrm{Hg}$ in soil potentially available for absorption in the human digestive system.

Table 2.4 Concentrations of different $\mathrm{Hg}$ species in different fractions of the ORR soil and SRM NIST 8406 by using sequential extraction procedure

\begin{tabular}{cccccccccc}
\hline \multicolumn{2}{c}{ Subsample type } & \multicolumn{7}{c}{ Hg concentrations (ng/g) in different fractions } \\
\cline { 2 - 9 } & & F1 & F2 & F3 & F4 & F5 & Sum & Total Hg Recovery (\%) \\
\hline redoximorphic & fine & $3.4 \pm 0.1$ & $2.5 \pm 0.4$ & $44.0 \pm 2.8$ & $16.6 \pm 1.0$ & $5.9 \pm 0.8$ & 72.4 & 76.7 & 94.3 \\
depletions & coarse & $3.7 \pm 0.8$ & $2.0 \pm 0.1$ & $35.6 \pm 3.6$ & $15.0 \pm 1.8$ & $6.8 \pm 0.4$ & 63.1 & 50.5 & 125.1 \\
redoximorphic & fine & $3.8 \pm 0.7$ & $3.2 \pm 0.5$ & $117.4 \pm 1.3$ & $47.3 \pm 9.1$ & $20.4 \pm 4.8$ & 192.1 & 203.2 & 94.5 \\
concentrations & coarse & $5.4 \pm 1.1$ & $3.1 \pm 0.1$ & $77.4 \pm 6.9$ & $33.3 \pm 6.7$ & $10.4 \pm 1.6$ & 129.6 & 121.9 & 106.3 \\
NIST 8406 & & $1.7 \pm 0.2$ & $1.3 \pm 0.2$ & $23.6 \pm 1.5$ & $10.2 \pm 0.8$ & $4.5 \pm 0.4$ & 41.3 & 60.0 & 68.8
\end{tabular}




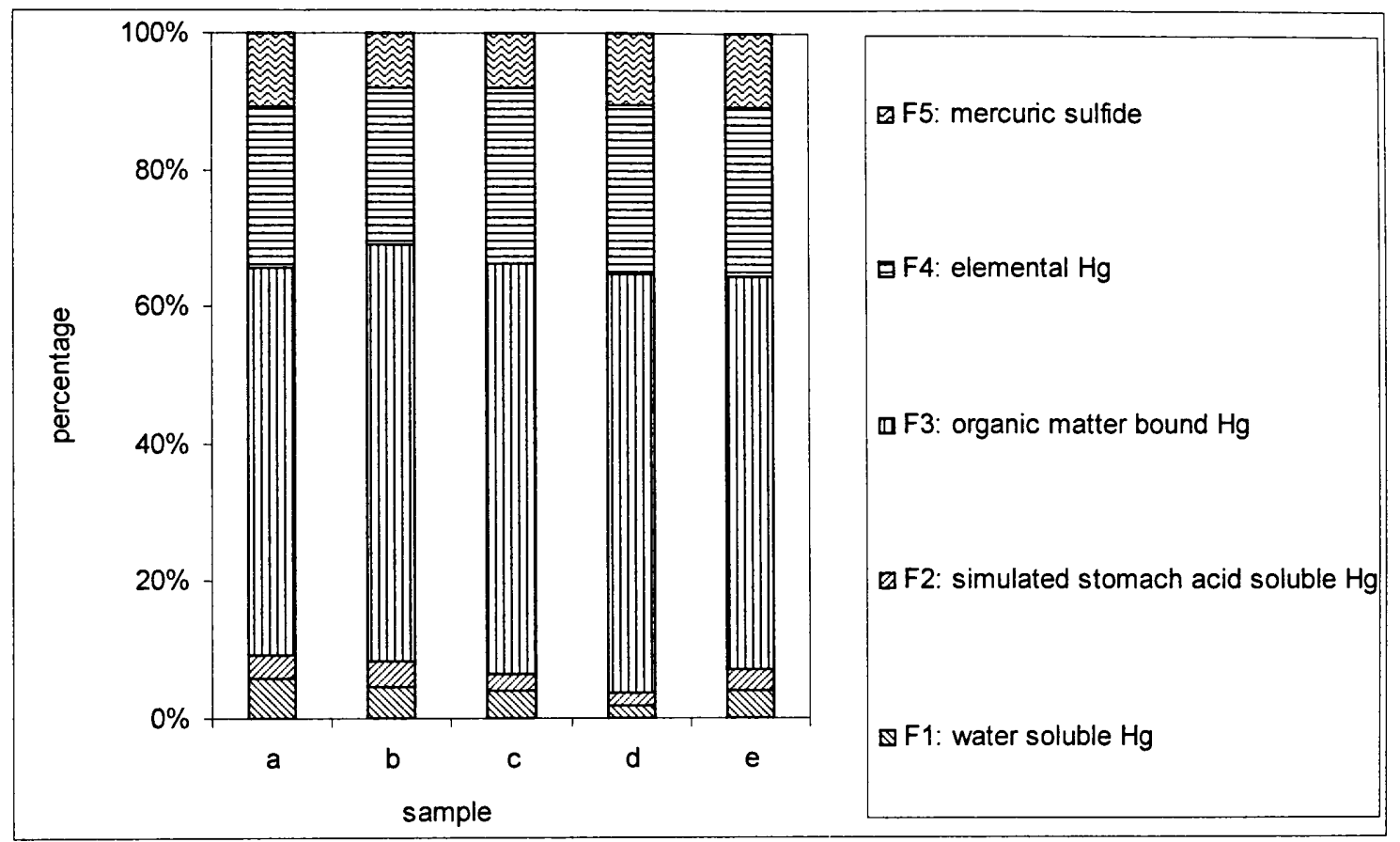

Fig. 2.4 Distribution of $\mathrm{Hg}$ in the freeze-dried subsamples from the ORR soil sample and the SRM NIST 8406 using sequential extraction. (a) Coarse redoximorphic depletions; (b) Fine redoximorphic depletions; (c) Coarse redoximorphic concentrations; (d) Fine redoximorphic concentrations; (e) NIST 8406

This kind of absorption through the gastrointestinal tract appears to be the most critical endpoint and exposure pathway for human community around $\mathrm{Hg}$ contaminated soil sites. Compared with the first two $\mathrm{Hg}$ fractions that were weakly associated with soil phase, F3 (Hg bound to organic matter) was regarded as stronger complex (Wallschlager et al., 1998b) and thus has limited mobility and bioavailability. As a result of its very low solubility, $\mathrm{F} 4\left(\mathrm{Hg}^{0}\right.$ likely plus other slightly soluble $\mathrm{Hg}$ species associated with soil particles) and F5 (insoluble mercuric sulfide) were not subject to transport or availability for chemical or biological transformation. It also should be borne in mind that: (1) $\mathrm{Hg}$ 
bound to organic matter (F3) could include methylmercury species (mainly monomethylmercury) in spite of being a very small proportion in general (Bloom et al., 2003); (2) organo-chelated $\mathrm{Hg}$ (F3) was observed to be strongly correlated with methylation potential and thus seems to play an important role in the biogeochemical cycle of $\mathrm{Hg}$ in some cases (Bloom et al., 2003; Ogrinc et al., 2007) and (3) Hg fractionation (and speciation) in soil/sediment is dynamic (Wallschlager et al., 1998b; Wallschlager et al., 1998c) and subject to shift with alteration of environmental conditions including physical, chemical factors, and especially microbial population and activities. For example, it has been reported that the presumably non-soluble cinnabar appeared to become soluble and form aqueous complexes with sulfide if it accumulated to a high enough concentration (Jay et al., 2000; Ravichandran M, 1998) because of sulfate reduction mediated by sulfate reducing bacteria (SRB) (Mason and Benoit, 2003).

It was observed that $\mathrm{Hg}$ in the redoximorphic concentrations was less labile than $\mathrm{Hg}$ in the redoximorphic depletions. In the redoximorphic depletions, the sum of F1 and F2 fraction (labile and bioavailable $\mathrm{Hg}$ fractions) accounted for $11.4 \%$ for coarse particles and $7.7 \%$ for fine particle. Lower proportions of F1 together with F2 were observed for the redoximorphic concentrations ( 7.7 and $3.4 \%$ for coarse and fine particle, respectively).

\subsubsection{Environmental implications}

Thermal desorption analysis showed that approximately $10-30 \%$ of total $\mathrm{Hg}$ in the ORR soil sample was $\mathrm{Hg}^{0}$ and other "easily" vaporized $\mathrm{Hg}$ species. Such a proportion was comparable with the F4 fraction (about 20-30\%) obtained in the sequential extraction 
procedure. The identical results obtained in these two different methods of speciation analysis provided a good estimation for $\mathrm{Hg}^{0}$ and other "easily" vaporized $\mathrm{Hg}$ species present in the ORR soil sample. Despite such an accountable "volatile" proportion, $\mathrm{Hg}$ in the studied soil seemed to be unfavorable to volatilization or to potentially produce inhaling toxicity because of bonding with the solid matrix. Lack of significant $\mathrm{Hg}$ release at less than $120^{\circ} \mathrm{C}$ indicated that $\mathrm{Hg}$ in this soil was relatively thermally stable and would not be thermally released under real-world environmental conditions.

The result of the present study suggested that both labile and bioavailable $\mathrm{Hg}$ fractions with high environmental risks were relatively small proportions in the studied ORR soil sample. Mercuric sulfide, previously reported as the dominant form of $\mathrm{Hg}$, was found not to be the most abundant form $(\sim 10 \%$ of total $\mathrm{Hg})$ in the studied soil sample. Such differences in $\mathrm{Hg}$ speciation could be attributed to the differences in sampling locations selected and probably, to a less extent, to the different sequential extraction procedures employed.

\subsection{Conclusions}

The redoximorphic concentrations contained higher $\mathrm{Hg}$ than the redoximorphic depletions. The higher content of Fe/Mn and organic matter was probably responsible for the higher $\mathrm{Hg}$ concentration in the redoximorphic concentrations. As expected, fine soil particles contained higher $\mathrm{Hg}$ compared with the coarse ones.

The results obtained using thermal desorption and sequential extraction procedure suggested that $\mathrm{Hg}$ retained in the redoximorphic concentrations was less volatile and labile than $\mathrm{Hg}$ in the redoximorphic depletions. With regards to the speciation of $\mathrm{Hg}$ in 
the soil, $10-30 \%$ of $\mathrm{Hg}$ species appeared to be $\mathrm{Hg}^{0}$ and other "easily" vaporized $\mathrm{Hg}$ species whereas organic matter bound $\mathrm{Hg}$ fraction was the major form of $\mathrm{Hg}$ species (accounting for $50 \%$ of total $\mathrm{Hg}$ ). 
Chapter 3 Analysis of mercury species in samples from ORR

\subsection{Introduction}

During the 1950's large amounts of mercury were released from Oak Ridge National Laboratories around the area of the East Fork Poplar Creek (EFPC) in Tennessee (Campbell et al., 1998; Han et al., 2009; Hollerman et al., 1999; Liu et al., 2006). Previous studies have indicated that the amount of total mercury in the soil ranges from 0.5 to $3000 \mathrm{ppm}$ (Revis and Osborne, 1989). Because of the severe contamination of $\mathrm{Hg}$, EFPC was placed on the National Priority List to undergo remediation through thermal desorption treatment and other techniques (Barnett and Harris, 1995, 1997; Barnett and Turner, 1995). A remedial investigation and feasibility study of Lower EFPC resulted in the signing of a Record of Decision (ROD) in August 1995. In response to the ROD, soil contaminated with $\mathrm{Hg}$ above $400 \mathrm{mg} / \mathrm{kg}$ was removed from two sites (NOAA facility and Bruner's) in LEFPC and the floodplain. Additional remediation practices were also and are being conducted in this area. It is not very clear about the magnitude of $\mathrm{Hg}$ contamination in this area after all these remedial activities. An extensive sampling in this area was conducted (see section 3.23) and samples were analyzed for THg and $\mathrm{MeHg}$ for water, soil, and sediment samples collected at a series of sites located along the water flow direction of the EFPC. The objective of this study is to characterize the magnitude of $\mathrm{Hg}$ contamination post remediation in the ORR area and determine the distribution patterns of $\mathrm{THg}$ and $\mathrm{MeHg}$ along the creek. 


\subsection{Experimental}

\subsubsection{Instrumentation}

A cold vapor atomic fluorescence spectrometer (CVAFS) system (Merlin 10.035, PS Analytical, UK) was used for mercury analysis. A Gyrotory shaker G2 from New Brunswick Scientific Co. Inc. and a Blue M oven were used for the sequential extraction procedure as well as for the thermal desorption analysis. For additional samples, a DMA80 Direct Mercury Analyzer from Milestone Inc. was used to determine the total mercury concentration in soil. A BioScience Ampulmatic Bench-Scale Ampule Sealer is also used to prepare the soil samples prior to digestion.

\subsubsection{Chemicals and Reagents}

Trace metal grade $\mathrm{HCl}$ and $\mathrm{HNO}_{3}$, analytical grade potassium bromide, potassium bromate, stannous chloride and other reagents all from Fisher Scientific were used for the mercury analysis. Mercury free DDI $\mathrm{H}_{2} \mathrm{O}$ was obtained in house produced by filtering tap water through a Culligan system consisting of activated charcoal and two mixed bed ion exchange cartridges. The filtered water is piped to a mercury-free clean room, where is passed through a Barnstead Mega-ohm B Pure system. A certified Hg standard 1000 ppm in $1.8 \% \mathrm{HNO}_{3}$ from Fischer Scientific was used as the primary standard. As a secondary mercury standard $1000 \mathrm{ppm}$ in $10 \% \mathrm{HNO}_{3}$ from SPEX was used as a calibration check. In addition, a river sediment standard reference material (SRM) NIST 8406, with nominal value of $60 \mathrm{ng} / \mathrm{g}$ of $\mathrm{Hg}$ and $5.50 \%$ for $\mathrm{Al}, 2.96 \%$ for $\mathrm{Fe}$, and $0.043 \%$ for $\mathrm{Mn}$, obtained from the National Institute of Standard and Technology. 
For total mercury analysis the following reagents will be prepared before the actual analysis begins. A solution of $0.2 \mathrm{M}$ Potassium bromide $(\mathrm{KBr})$ is prepared by weighing $11.900 \mathrm{~g}$ of $\mathrm{KBr}$ and heating overnight in a glass scintillation vial (Kimble 74511 ) at $250{ }^{\circ} \mathrm{C}+/-20^{\circ} \mathrm{C}$ in a furnace to remove mercury. After cooling, the $\mathrm{KBr}$ is dissolved in $500 \mathrm{ml}$ of DIW and stored in a borosilicate bottle. This solution is prepared on a weekly basis.

A $0.1 \mathrm{M}$ Potassium bromate $\left(\mathrm{KBrO}_{3}\right)$ is prepared by weighing approximately $8.385 \mathrm{~g}$ of $\mathrm{KBrO} 3$ and heating it also overnight in a glass scintillation vial (Kimble 74511 ) at $250{ }^{\circ} \mathrm{C}+/-20^{\circ} \mathrm{C}$ in a furnace to remove mercury. After cooling, the $\mathrm{KbrO}_{3}$ is dissolved in $500 \mathrm{ml}$ of DIW and stored in a borosilicate bottle. It is prepared on a weekly basis.

A Mixed brominating reagent $(0.1 \mathrm{M}$ Potassium bromide $(\mathrm{KBr}): 0.05 \mathrm{M}$ Potassium bromate $\left.\left(\mathrm{KBrO}_{3}\right)\right)$ is then prepared by mixing equal volumes $(100 \mathrm{ml})$ of potassium bromate and potassium bromide solutions in a 250 borosilicate bottle with a Teflon cap. It is also prepared on a weekly basis.

A $12 \%(\mathrm{w} / \mathrm{v})$ Hydroxylamine hydrochloride $\left(\mathrm{NH}_{2} \mathrm{OH} . \mathrm{HCl}\right)$ is prepared by weighing $6.0 \mathrm{~g}$ of $\mathrm{NH}_{2} \mathrm{OH} . \mathrm{HCl}$ and dissolving it in $50 \mathrm{ml}$ of DIW in a $60 \mathrm{ml}$ Teflon bottle. It is prepared on a weekly basis. It is added to destroy the excess bromine before analysis. Also, to reduce $\mathrm{Hg}^{2+}$ compounds present in solution to $\mathrm{Hg}^{0}$, a $2 \%(\mathrm{w} / \mathrm{v})$ stannous chloride $\left(\mathrm{SnCl}_{2}\right)$ is prepared by adding $50 \mathrm{ml}$ of $12 \mathrm{~N} \mathrm{HCl}$ and $40 \mathrm{~g}$ of $\mathrm{SnCl}_{2} .2 \mathrm{H} 2 \mathrm{O}$ and the volume is then completed up to $2000 \mathrm{ml}$ using DIW. Purged with argon for 20 minutes before running samples. It is also prepared on a weekly basis. In 
addition, a $1 \% \mathrm{HCl}$ solution is prepared to be used as wash water for the AFS system during the actual analysis.

\subsubsection{Sampling site selection}

A total of 54 environmental samples were taken from the LEFPC area. Creek water, creek bank soil cores at 4-8" above water level, sediment cores, and creek-creek bank vegetation samples were taken at points along the length of the creek. The sampling site was located $1 / 4$ mile from the $\mathrm{Y}-12$ complex site, and directly behind a commercial car wash (Mullins Car Wash). After collection the samples were sent overnight under dry ice from Oak Ridge to Miami and then placed either in a $-20{ }^{\circ} \mathrm{C}$ freezer for storage until analyzed. Figure 3.1 shows the locations of the sampling sites.

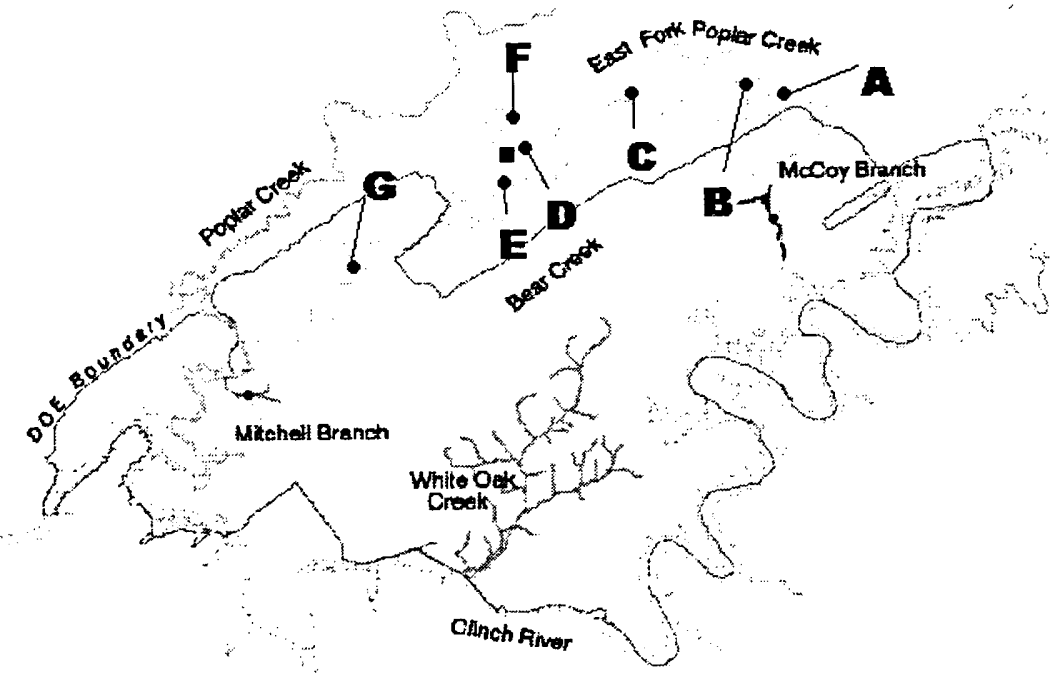

Figure 3.1 Sampling points along the LEFPC: (A) behind Mullins' Car Wash; (B) behind the NOAA facility; (C) at the Bruner Site; (D) Pre-Wastewater Treatment Plant; (E) Post-Wastewater Treatment Plant; (F) at Robertsville Junior High School; (G) at the Horizon Center on the ORR. 


\subsection{Procedure}

\subsubsection{Total mercury in soil and sediment}

Soil and sediment samples $(0.1$ to $0.3 \mathrm{~g})$ were placed inside a $10 \mathrm{ml}$ of Wheaton glass ampule. Effort was made to select homogenized samples by taking them from different areas of the bulk sample. Triplicates were made for each sample, and each of these was analyzed at least three times. To each ampule $1 \mathrm{ml}$ of $\mathrm{H}_{2} \mathrm{O}$ and $2 \mathrm{ml}$ of concentrated $\mathrm{HNO}_{3}$ were added. Then the samples were allowed to settle for at least 20 minutes before sealing so that any gas produced was released from the ampule prior to closing. Afterward, each ampule was sealed using an Ampulmatic Ampule Sealer and digested in an autoclave at $120^{\circ} \mathrm{C}$ for 1 hour. After removing the ampules from the autoclave, they were allowed to cool and were then analyzed. An extra sample for each type of sediment and soil was weighed and dried overnight at $80^{\circ} \mathrm{C}$ in a regular oven in order to determine the wet-to-dry ratio. This ratio was used to report the mercury concentration on a dry-weight basis.

\subsubsection{Total mercury in water}

The procedure used is based on the SERC standard operating procedure for total mercury determination in water. Prior to analysis, $5 \mathrm{ml}$ of concentrated trace metal grade $\mathrm{HCl}$ is added per liter of sample $(0.5 \%)$ for preservation purpose. These additions are done in an $\mathrm{Hg}$ clean room. For each individual sample, three $125 \mathrm{ml}$ Teflon bottles are filled to the $125 \mathrm{ml}$ line with the sample water. The samples are placed in an ultraviolet cabinet for 12 hours and allowed to cool. Placing the samples in the UV cabinet 
destroys any organic matter present in the solution. Then, $0.6 \mathrm{ml}$ of $12 \mathrm{~N} \mathrm{HCl}$ (to complete $1 \% \mathrm{HCl}$ ) and $2.5 \mathrm{ml}$ of $\mathrm{KbrO} 3 / \mathrm{KBr}$ mixed brominating reagent are added to each bottle. After one hour, $500 \mu \mathrm{l}$ of $12 \%(\mathrm{w} / \mathrm{v})$ hydroxylamine hydrochloride are added to inhibit any further reaction. Samples are allowed to settle for at least $10 \mathrm{~min}$ before analysis.

An extra $125 \mathrm{ml}$ aliquot of one of the samples included in the run (one per sample set) is obtained to be used as a Matrix Spike sample. Then $1.25 \mathrm{ml}$ of the sample is removed from the bottle and replaced by $1.25 \mathrm{ml}$ of the $100 \mathrm{ppt}$ working calibration standard to yield a final spiked mercury concentration of $1 \mathrm{ppt}$.

A six point calibration curve is prepared $(0,0.5,2.5,5,10$, and $25 \mathrm{ppt})$ in $1 \% \mathrm{HCl}$ from the 1000ppm primary standard from Fisher. Also, an additional standard $5 \mathrm{ppt}$ using the SPEX total mercury standard is prepared as a check standard.

Three reagent blanks containing different amounts of reagents are digested to determine the amount of mercury added to each sample by them. The reagent blanks are prepared by filling three $125 \mathrm{ml}$ bottles with DIW from the mercury-free room and carrying out the following procedure: Reagent blank I : $1.8 \mathrm{ml}$ of DIW are removed from the Reagent I bottle and $1.25 \mathrm{ml} \mathrm{KBrO}_{3} / \mathrm{KBr} \operatorname{mix}, 0.3 \mathrm{ml} \mathrm{HCl}$, and $0.25 \mathrm{ml}$ hydroxylamine are consecutively added. Reagent blank II: $3.6 \mathrm{ml}$ of DIW are removed from the Reagent II bottle and $2.50 \mathrm{ml} \mathrm{KBrO}_{3} / \mathrm{KBr}$ mix, $0.6 \mathrm{ml} \mathrm{HCl}$, and $0.50 \mathrm{ml}$ hydroxylamine are consecutively added. Reagent blank III: $7.2 \mathrm{ml}$ of DIW are removed

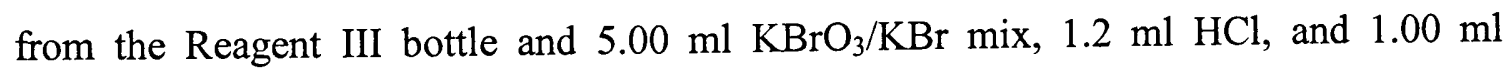
hydroxylamine are consecutively added. The reagent blanks are analyzed in $125 \mathrm{ml}$ Teflon bottles along with the samples and each bottle is analyzed at least three times. 


\subsubsection{Methylmercury in soil and sediment}

A total of 41 sediment samples were sent to Frontier Geosciences Inc. (414 Pontius Ave. North. Seattle, WA 98109), because of the lack of available working equipment. Methylmercury samples were analyzed via cold vapor gas chromatography fluorescence spectrometry (CV-GC-AFS).

Samples were processed using ultra- clean sample handling techniques in laminar flow clean areas known to be low in atmospheric trace metals. Reagents, gases, and deionized water are all reagent or ultra pure grade, and were previously analyzed for trace metals to ensure low blank results. Daily analytical runs were begun with a 5 point standard curve, spanning the entire analytical range of interest, with an additional run every 10 samples. The daily standard curves were calculated using the blank-corrected initial standards, with a linear regression forced through zero. For each analytical set, one matrix duplicate, two matrix spikes, and at leas three method blanks were co-processed and analyzed in exactly the same manner as ordinary samples.

Because of significant positive monomethylmercury $\mathrm{MMHg}$ artifact formation during the distillation of samples containing high levels of inorganic $\mathrm{Hg}$ (Bloom et al., 1997), the sediment and soil samples were cold extracted rather than distilled. Aliquots of these samples, approximately $0.5 \mathrm{~g}$, were accurately weighed into $40 \mathrm{ml}$ Teflon centrifuge tubes, and $5 \mathrm{ml}$ of $\mathrm{H}_{2} \mathrm{SO}_{4} / \mathrm{KBr}$ solution plus $1 \mathrm{ml}$ of $1 \mathrm{M} \mathrm{CuSO}_{4}$ were added. After mixing, $10 \mathrm{ml}$ of methylene chloride $\left(\mathrm{CH}_{2} \mathrm{CL}_{2}\right)$ was added to each tube, and the samples were shaken for 1 hour. The samples were then centrifuged at 3000 RPM for 30 minutes to separate the solvent from the aqueous layer. Exactly $2.0 \mathrm{ml}$ of $\mathrm{CH}_{2} \mathrm{CL}_{2}$ were removed 
from each sample and pipetted into a Teflon vial containing $57.6 \mathrm{ml}$ of deionized water. The samples were heated to $45{ }^{\circ} \mathrm{C}$ and purged with $\mathrm{N}_{2}$ to volatilize the $\mathrm{CH}_{2} \mathrm{Cl}_{2}$, thus releasing the $\mathrm{MMHg}$ to the pure aqueous phase.

Aliquots of extracted samples were analyzed using aqueous phase ethylation, purging onto Carbotrap, isothermal GC separation, and cold vapor atomic fluorescence spectrometry (CVAFS) detection. Prior to ethylation, the $\mathrm{pH}$ of the sample was brought to 4.9 with the addition of acetate buffer. Samples were ethylated by the addition of sodium tetraethyl borate, and then the volatile ethyl analogs purged with $\mathrm{N}_{2}$ onto Carbotrap. After a trap drying step, the mercury ethyl analogs were thermally desorbed into a $1 \mathrm{~m}$ isothermal GC column (15\% OV-3 on Chromasorb WAW-DMSC) held at $100^{\circ} \mathrm{C}$ for separation. The column resolves the following peaks: elemental $\mathrm{Hg}$, dimethyl $\mathrm{Hg}$, methyl ethyl $\mathrm{Hg}$, and diethyl Hg. Because of the wet chemistry used, only methyl ethyl $\mathrm{Hg}$, the $\mathrm{MMHg}$ analog is quantified for this assay. The organo- $\mathrm{Hg}$ compounds are pyrolytically broken down to $\mathrm{Hg}^{0}$ prior to entering the CVAFS detector for quantification.

\subsection{Results and Discussion}

3.4.1 Initial evaluation of total mercury concentrations in ORR area.

Prior to the large scale sampling and sample analysis for soil, sediment, and water samples in the ORR area, a pilot study was conducted to evaluate the concentration levels of $\mathrm{Hg}$ in this area. Another purpose of conducting such a pilot study was to identify potential problems associated with sampling, sample transfer, sample storage, and sample analysis that may be encountered during the large scale study. In this pilot study, four 
samples were originally received: a soil sample HCET-D094-004-S, a sediment sample HCET-D094-003-SD, and 2 water samples HCET-D094-001-W and HCET-D094-002W. Additional water samples labeled as HCET-D094-005-W, HCET-D094-006-W, and sediment samples HCET-D094-0-11-50 BOTTOM, HCET-D094-0-11-50 TOP, HCETD094-0-10-S BOTTOM, HCET-D094-0-10-S TOP were also received. These samples were analyzed to assess the level of mercury contamination just outside the Y-12 boundary of the ORR site.

Total mercury concentrations in the Oak Ridge samples for the initial sampling episode are found in Table 3.1. The results for soil and sediment samples were calculated on a dry weight basis. It should be noted that for this analytical round, high standard deviations (STDEV) were observed for soil samples. The high STDEV could be attributed to the lack of homogeneity in the samples received. The original sample was analyzed as received, without freeze-drying, in an effort to minimize possible losses of elemental and volatile species of mercury. The soil, however, was clearly composed of two parts, a brownish part or "clay", redoximorphic concentrations and a gray part or the "sandy" fraction, redoximorphic depletions. Higher concentrations have been obtained for all samples analyzed, compared to the background levels of $\mathrm{Hg}$ in water (generally less than $10 \mathrm{ng} / \mathrm{L}$ ) and soil (about $100 \mathrm{ng} / \mathrm{g}$ ), indicating that this area has been heavily contaminated with $\mathrm{Hg}$. In consideration of high concentrations of $\mathrm{Hg}$ present in ORR soil, a DMA-80 Direct Mercury Analyzer (DMA) from Milestone Inc. was used to determine the total mercury concentration in soil. The selection of DMA-80, over acid digestion-CVAFS method, for soil THg determination can significantly reduce the cost and time associated sample analysis. 
Table 3.1 Total mercury concentrations in ORR samples during initial sampling event

\begin{tabular}{lcc}
\hline Sample ID & Concentration & STDEV \\
\hline Soil/sediment & $(\boldsymbol{n g} / \boldsymbol{g})$ & $(\boldsymbol{n} \boldsymbol{g} / \boldsymbol{g})$ \\
\hline HCET- D094-004-S & 137.9 & 72.2 \\
HCET-D094-003-SD & 10,489 & 2,043 \\
HCET-D094-0-11-50 TOP & 394.7 & 217.2 \\
HCET-D094-0-11-50 BOTTOM & 587.3 & 167.2 \\
HCET-D094-0-10-S TOP & 833.9 & 113.6 \\
HCET-D094-0-10-S BOTTOM & 72.7 & 32.1 \\
\hline Water & $(\boldsymbol{n g} / \mathbf{L})$ & $(\boldsymbol{n} \boldsymbol{g} / \mathbf{L})$ \\
\hline HCET- D094-001-W & 670.3 & 31.0 \\
HCET- D094-002-W & 280.5 & 5.3 \\
HCET-D094-005-W & 596.6 & 18.7 \\
HCET-D094-006-W & 637.6 & 12.7 \\
\hline
\end{tabular}

3.4.2 Survey of the mercury problem in the ORR area

Over 40 samples (including soil, sediment and water samples) were analyzed at mercury contaminated site surrounding the Y-12 area in order to assess the dimensions of the $\mathrm{Hg}$ contamination in the area. The results (Table 3.2) showed that environmental compartments surrounding the Oak Ridge contained high concentration of $\mathrm{Hg}$, though varying remarkably depending upon different environmental media types and sampling locations. The $\mathrm{Hg}$ concentrations in surrounding the Oak Ridge area ranged from 50 to $45,000 \mathrm{ng} / \mathrm{g}$. The soil samples had similar magnitude of $\mathrm{Hg}$ concentration with sediment samples. Four water samples in this area were analyzed and very high $\mathrm{Hg}$ concentrations 
with the range from 280.5 to $670.3 \mathrm{ng} / \mathrm{L}$ were observed. All these analysis data indicated that this sampling area was heavily contaminated with $\mathrm{Hg}$ in comparison to a background concentration of $112 \mathrm{ng} / \mathrm{g}$ for soil in continental USA (Andersson, 1979). The $\mathrm{Hg}$ concentration observed in the present study appeared to be comparable with previous results $(15-2630 \mu \mathrm{g} / \mathrm{g})$ determined by other authors in related area though present results seemed to be a bit lower than previous data probably due to different sampling locations (Barnett and Harris, 1997).

It should be noted that, however, high standard deviations (STDEV) were observed for certain samples such as HCET-D094-004-S, HCET-D094-038-S, HCETD094-0-11-50 TOP, HCET- D094-0-10-S BOTTOM soil samples and HCET-D094-043SD sediment sample (about 40-50\% RSD). The high STDEV could be attributed to the lack of homogeneity of the sample used. Original sample was used without freeze-drying in an effort to minimize possible loss of elemental and volatile species of $\mathrm{Hg}$.

Table 3.2 Mercury concentrations in the selected soil, sediment, and water samples collected from Oak Ridge LEFPC mercury-contaminated samples

\begin{tabular}{lllll}
\hline \multicolumn{1}{c}{ Sample Name } & \multicolumn{1}{c}{ Location } & \multicolumn{1}{c}{$\begin{array}{c}\text { Average Conc. } \\
\text { (ng/g) }\end{array}$} & \multicolumn{1}{c}{ STDEV } & \multicolumn{1}{c}{ RSD } \\
\hline & \multicolumn{1}{c}{ SOIL } & & & \\
\hline HCET-D094-004-S & Behind Mullins' Car Wash & 137.91 & 72.19 & 52.35 \\
HCET-D094-031-S & LEFPC @ NOAA Site & 37155.41 & 4764.63 & 12.82 \\
HCET-D094-032-S & LEFPC @ NOAA Site & 30485.83 & 3044.91 & 9.99 \\
HCET-D094-038-S & LEFPC @ Bruner's Site & 4389.80 & 1680.85 & 38.29 \\
HCET-D094-039-S & LEFPC @ Bruner's Site & 1042.26 & 36.88 & 3.54 \\
HCET-D094-018-S & Pre WWTP(S. Monterey Rd.) & 26368.89 & 1297.56 & 4.92 \\
HCET-D094-024-S & Post WWTP(Gum Hollow Rd.) & 1626.92 & 120.30 & 7.39 \\
HCET-D094-052-S & Robertsville & 23219.50 & 4580.60 & 19.73 \\
HCET-D094-053-S & Robertsville & 28554.32 & 5163.77 & 18.08 \\
HCET-D094-045-S & Horizon Center & 10173.76 & 3405.76 & 33.48 \\
HCET-D094-046-S & Horizon Center & 2299.01 & 163.57 & 7.11 \\
HCET-D094-058-S & Mouth of Fork & 226.61 & 26.27 & 11.59 \\
HCET-D094-065-S & South Perimeter Road & 1208.20 & 78.17 & 6.47 \\
\hline
\end{tabular}




\begin{tabular}{|c|c|c|c|c|}
\hline HCET-D094-072-ORNL-4 & Hinds Creek & 58.97 & 8.70 & 14.75 \\
\hline HCET- D094-0-11-50 BOTTOM & & 587.3 & 167.2 & 28.47 \\
\hline HCET- D094-0-11-50 TOP & & 394.7 & 217.2 & 55.03 \\
\hline HCET- D094-0-10-S BOTTOM & & 72.7 & 32.10 & 44.15 \\
\hline HCET- D094-0-10-S TOP & & 833.9 & 113.6 & 13.62 \\
\hline \multicolumn{5}{|c|}{ SEDIMENT } \\
\hline HCET - D094 -003-SD & Behind Mullins' Car Wash & 10488.67 & 2043.06 & 19.48 \\
\hline HCET-D094-029-SD & LEFPC@NOAA Site & 5436.58 & 749.65 & 13.79 \\
\hline HCET-D094-030-SD & LEFPC@NOAA Site & 8955.74 & 1509.66 & 16.86 \\
\hline HCET-D094-036-SD & LEFPC@ Bruner’s Site & 57.68 & 6.60 & 11.44 \\
\hline HCET-D094-037-SD & LEFPC@ Bruner's Site & 65.80 & 5.94 & 9.03 \\
\hline HCET-D094-015-SD & Pre WWTP (S. Monterey Rd.) & 12534.24 & 166.63 & 1.33 \\
\hline HCET-D094-016-SD & Pre WWTP (S. Monterey Rd.) & 13849.02 & 1824.54 & 13.17 \\
\hline HCET-D094-022-SD & Post WWTP (Gum Hollow Rd.) & 60.32 & 6.18 & 10.25 \\
\hline HCET-D094-023-SD & Post WWTP (Gum Hollow Rd.) & 975.07 & 148.94 & .15 .27 \\
\hline HCET-D094-050-SD & Robertsville & 2592.19 & 335.17 & 12.93 \\
\hline HCET-D094-051-SD & Robertsville & 13231.95 & 1939.75 & 14.66 \\
\hline HCET-D094-043-SD & Horizon Center & 13117.65 & 5979.92 & 45.59 \\
\hline HCET-D094-044-SD & Horizon Center & 23764.76 & 3516.43 & 14.80 \\
\hline HCET-D094-057-SD & Mouth of Fork & 550.48 & 50.27 & 9.13 \\
\hline HCET-D094-059-SD & Mouth of Fork & 9354.38 & 1895.61 & 20.26 \\
\hline HCET-D094-060-SD & Mouth of Fork & 89.50 & 3.76 & 4.20 \\
\hline HCET-D094-064-SD & South Perimeter Road & 5069.25 & 1621.11 & 31.98 \\
\hline HCET-D094-066-SD & South Perimeter Road & 1837.62 & 153.70 & 8.36 \\
\hline HCET-D094-067-SD & South Perimeter Road & 1798.03 & 335.91 & 18.68 \\
\hline HCET-D094-069-ORNL-1 & Hinds Creek & 132.99 & 39.45 & 29.66 \\
\hline HCET-D094-070-ORNL-2 & EFK 23.4 & 45102.34 & 2826.45 & 6.27 \\
\hline HCET-D094-071-ORNL-3 & EFK 6.3 & 6913.36 & 683.09 & 9.88 \\
\hline \multicolumn{5}{|c|}{ WATER } \\
\hline HCET-D094-001-W & Behind Mullins' Car Wash & 670.27 & 30.96 & 4.62 \\
\hline HCET-D094-002-W & Behind Mullins' Car Wash & 280.45 & 5.30 & 1.89 \\
\hline HCET-D094-005-W & Behind Mullins' Car Wash & 596.6 & 18.70 & 3.13 \\
\hline HCET-D094-006-W & Behind Mullins' Car Wash & 637.6 & 12.70 & 1.99 \\
\hline
\end{tabular}

\subsubsection{Methylmercury in ORR soil and sediment}

The methylmercury concentrations in ORR soil and sediment samples were illustrated in Table 3.3. Samples were collected from three locations, i.e., Mullins Carwash, Bruner's site, and Horizon center (see Fig. 3.1). For each site, both soil and sediment samples were collected. The results of $\mathrm{MeHg}$ analysis suggested that, similar to THg, MeHg exhibited a fairly wide concentration range in the ORR soil and sediment (Table 3.3). The soil $\mathrm{MeHg}$ can vary from 0.4 (similar to background levels in uncontaminated areas) to up to $60 \mathrm{ng} / \mathrm{g}$ (a level rarely observed in environmental 
matrices). The sediment $\mathrm{MeHg}$ in the ORR can range from 0.2 to over $20 \mathrm{ng} / \mathrm{g}$, depending upon the sampling location. The observation of fairly high $\mathrm{MeHg}$ concentrations in a variety of samples (including soil and sediment) collected from the ORR is indicative of heavy $\mathrm{Hg}$ contamination in this area.

It was observed that soil $\mathrm{MeHg}$ exhibited a different pattern of distribution among these 3 sampling sites than sediment $\mathrm{MeHg}$ did. For soil $\mathrm{MeHg}$, Mullins carwash was the highest while no significant difference was observed between Bruner's site and Horizon center (Fig. 3.2A). The mean concentrations of soil MeHg for mullins carwash, Bruner's site, and Horizon center were 30.1, 4.79, $4.05 \mathrm{ng} / \mathrm{g}$, respectively. For sediment $\mathrm{MeHg}$, Horizon center was highest, compared to the other two locations (Fig 3.2B). The mean concentrations of sediment MeHg for mullins carwash, Bruner's site, and Horizon center were $3.46,0.632,10.4 \mathrm{ng} / \mathrm{g}$, respectively.

In consideration that these 3 sampling sites located along the downward direction of the EFPC, with the water flow direction from Mullins carwash site to Bruner's site to Horizon center. The Hg source to the EFPC is located around the headwater of this creek. One might speculate that the distribution of $\mathrm{MeHg}$ in soil and sediment should be related to $\mathrm{THg}$ distribution patterns along the creek. A quick check of $\mathrm{THg}$ distribution along the EFPC suggested that clear spatial patterns were not present for THg in soil (Fig. 3.3A) or in sediment (Fig. 3.3B), which might be a result of the long-time discharge of $\mathrm{Hg}$ from the DOE facility around the headwater of EFPC during the past several decades. The discrepancy between $\mathrm{THg}$ and $\mathrm{MeHg}$ distribution along the creek suggested that the differences in $\mathrm{Hg}$ methyltion/demethylation among different sampling site, in addition to $\mathrm{THg}$ distribution, play an important role in determining $\mathrm{MeHg}$ distribution patterns. 
Further studies in respect of biogeochemical characteristics of different sampling sites and their effects on $\mathrm{Hg}$ methylation/demethylation are needed to better understand the $\mathrm{Hg}$ problems in this area.

Table 3.3 Methylmercury concentrations in ORR soil and sediment samples

\begin{tabular}{|c|c|c|c|c|c|}
\hline \multirow[t]{2}{*}{ Sample ID } & \multirow{2}{*}{$\begin{array}{c}\text { Site } \\
\text { location }\end{array}$} & \multirow{2}{*}{$\begin{array}{c}\text { Sample } \\
\text { type }\end{array}$} & \multirow[t]{2}{*}{$\%$ total Solids } & \multicolumn{2}{|c|}{ Methyl Hg (ng/g) } \\
\hline & & & & wet weight & dry weight \\
\hline HCET-D094-MT1 & Mullins Carwash & Soil & 73.9 & 17.9 & 24.2 \\
\hline HCET-D094-MT2 & Mullins Carwash & Soil & 72.7 & 43.8 & 60.2 \\
\hline HCET-D094-MT3 & Mullins Carwash & Soil & 71 & 26.2 & 36.9 \\
\hline HCET-D094-MT4 & Mullins Carwash & Soil & 74.7 & 19.4 & 26 \\
\hline HCET-D094-MT5 & Mullins Carwash & Soil & 77.5 & 11.3 & 14.6 \\
\hline HCET-D094-MT6 & Mullins Carwash & Soil & 76.3 & 14.2 & 18.7 \\
\hline HCET-D094-MT1SD & Mullins Carwash & Sediment & 43.3 & 3.28 & 7.58 \\
\hline HCET-D094-MT2SD & Mullins Carwash & Sediment & 83.5 & 4.06 & 4.87 \\
\hline HCET-D094-MT3SD & Mullins Carwash & Sediment & 76.7 & 1.11 & 1.44 \\
\hline HCET-D094-MT4SD & Mullins Carwash & Sediment & 73.6 & 1.66 & 2.26 \\
\hline HCET-D094-MT5SD & Mullins Carwash & Sediment & 80 & 1.79 & 2.24 \\
\hline HCET-D094-MT6SD & Mullins Carwash & Sediment & 71.9 & 1.7 & 2.36 \\
\hline HCET-D094-BG1B & Bruner's Site & Soil & 82.4 & 1.34 & 1.63 \\
\hline HCET-D094-BG2B & Bruner's Site & Soil & 85.7 & 0.32 & 0.373 \\
\hline HCET-D094-BG3B & Bruner's Site & Soil & 82.8 & 0.326 & 0.394 \\
\hline HCET-D094-BG4B & Bruner's Site & Soil & 83 & 0.787 & 0.948 \\
\hline HCET-D094-BG5B & Bruner's Site & Soil & 80.1 & 9.28 & 11.6 \\
\hline HCET-D094-BG6B & Bruner's Site & Soil & 78.7 & 5.52 & 7.02 \\
\hline HCET-D094-BG7B & Bruner's Site & Soil & 80 & 7.79 & 9.73 \\
\hline HCET-D094-BG8B & Bruner's Site & Soil & 81.8 & 7.63 & 9.33 \\
\hline HCET-D094-BG9B & Bruner's Site & Soil & 85.7 & 1.21 & 1.41 \\
\hline HCET-D094-BG10B & Bruner's Site & Soil & 85 & 0.703 & 0.827 \\
\hline HCET-D094-BG11B & Bruner's Site & Soil & 82.7 & 7.78 & 9.41 \\
\hline HCET-D094-BG2D-SD & Bruner's Site & Sediment & 80.8 & 0.148 & 0.183 \\
\hline HCET-D094-BG4C-SD & Bruner's Site & Sediment & 74.6 & 0.154 & 0.206 \\
\hline HCET-D094-BG6C-SD & Bruner's Site & Sediment & 78.2 & 0.149 & 0.191 \\
\hline HCET-D094-BG6E-SD & Bruner's Site & Sediment & 79.1 & 1.02 & 1.29 \\
\hline HCET-D094-BG7-A & Bruner's Site & Sediment & 77.5 & 1.41 & 1.82 \\
\hline HCET-D094-BG11-A & Bruner's Site & Sediment & 74.5 & 0.075 & 0.101 \\
\hline HCET-D094-HT1 & Horizon Center & Soil & 79.7 & 4.38 & 5.49 \\
\hline HCET-D094-HT2 & Horizon Center & Soil & 81.8 & 2.99 & 3.65 \\
\hline HCET-D094-HT3 & Horizon Center & Soil & 83.6 & 2.35 & 2.82 \\
\hline HCET-D094-HT4 & Horizon Center & Soil & 89.2 & 4.08 & 4.57 \\
\hline HCET-D094-HT5 & Horizon Center & Soil & 82.8 & 2.91 & 3.52 \\
\hline HCET-D094-HT6 & Horizon Center & Soil & 81.9 & 3.48 & 4.25 \\
\hline HCET-D094-HT1SD & Horizon Center & Sediment & 63.6 & 14.8 & 23.3 \\
\hline HCET-D094-HT2SD & Horizon Center & Sediment & 70 & 5.29 & 7.56 \\
\hline HCET-D094-HT3SD & Horizon Center & Sediment & 61.9 & 5.51 & 8.9 \\
\hline HCET-D094-HT4SD & Horizon Center & Sediment & 66.6 & 12.6 & 18.9 \\
\hline HCET-D094-HT5SD & Horizon Center & Sediment & 76.2 & 1.45 & 1.9 \\
\hline HCET-D094-HT6SD & Horizon Center & Sediment & 71.3 & 1.1 & 1.55 \\
\hline
\end{tabular}



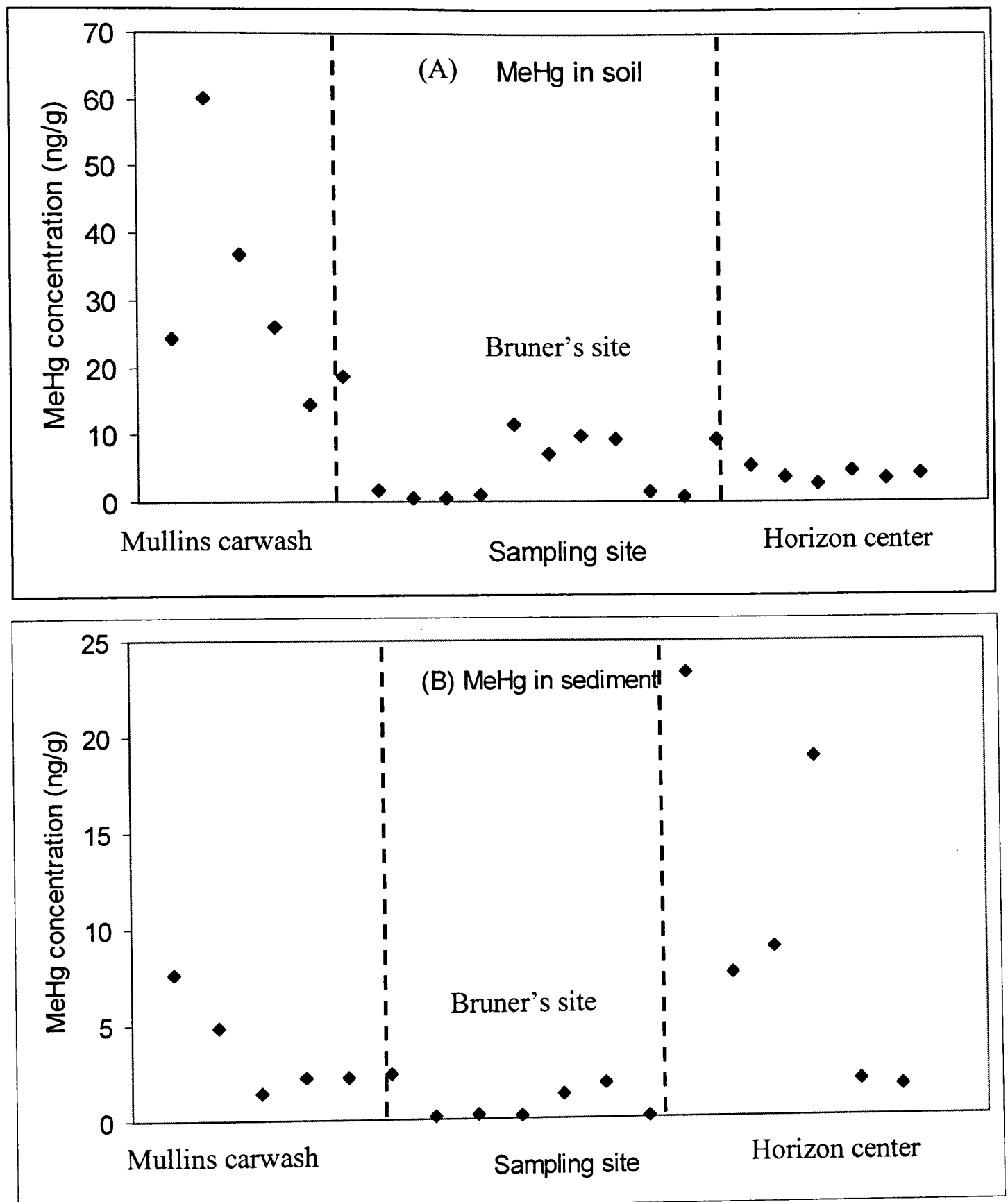

Fig. 3.2 Distribution of $\mathrm{MeHg}$ in soil and sediment along the EFPC 

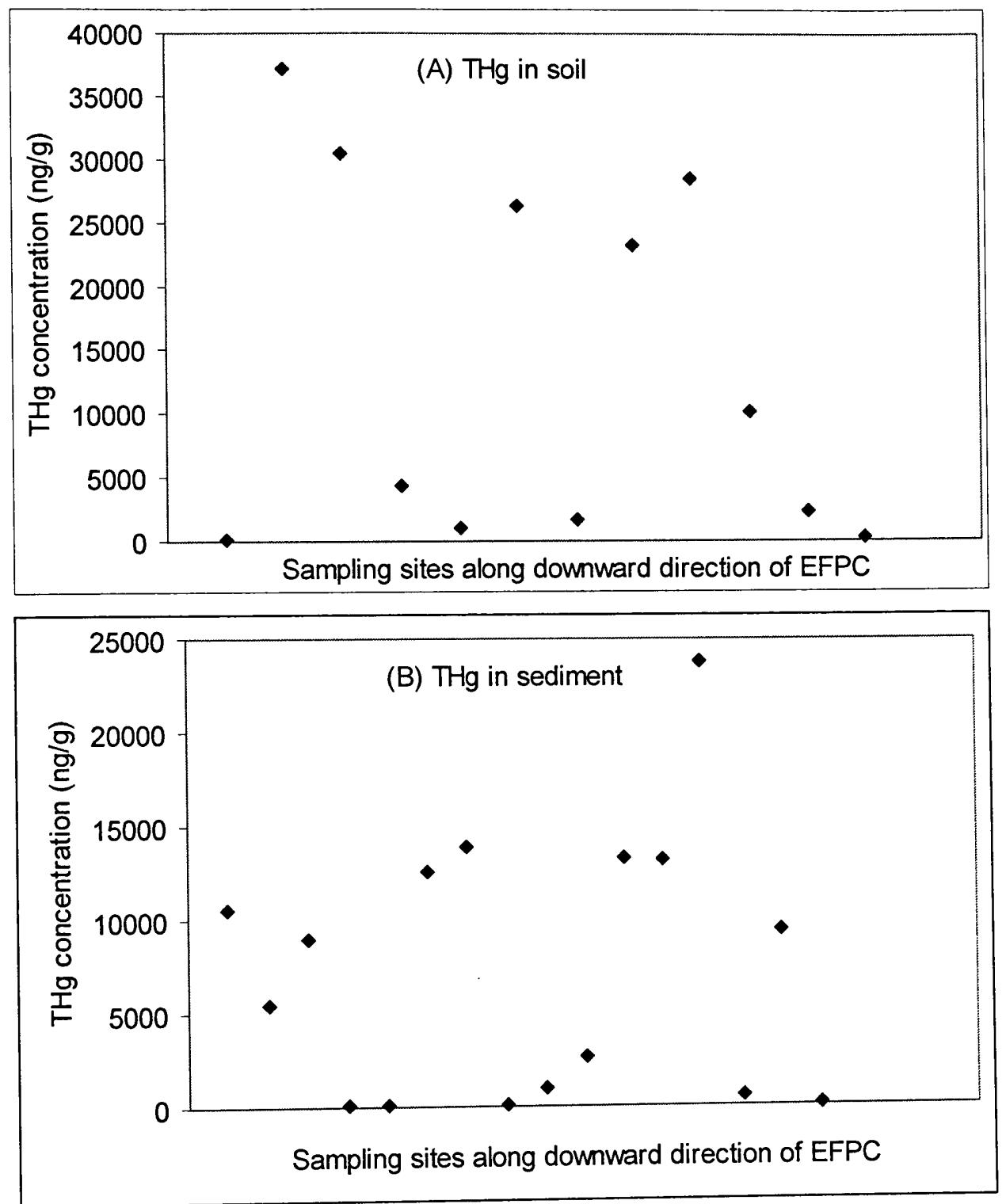

Fig. 3.3 Distribution of THg in soil and sediment along the EFPC

\subsection{Conclusions}

Total mercury concentrations ranged from 50 to $45,000 \mathrm{ng} / \mathrm{g}$ while $\mathrm{MeHg}$ varied from 0.2 to $60 \mathrm{ng} / \mathrm{g}$ in the ORR soil and sediment samples. The observation of fairly high $\mathrm{THg}$ as well as $\mathrm{MeHg}$ concentrations indicated that this area still has severe $\mathrm{Hg}$ 
contamination problem, despite that some remedial measures were adopted in the past two decades. Both $\mathrm{THg}$ and $\mathrm{MeHg}$ concentrations varied remarkably depending upon different sampling locations and environmental matrices sampled. Clear spatial patterns were not present for $\mathrm{THg}$ distribution along the EFPC, suggesting that long-time discharge of $\mathrm{Hg}$ from the DOE facility has extensively spread $\mathrm{Hg}$ contamination in this area. Spatial patterns were observed for $\mathrm{MeHg}$ in soil and in sediment, although the patterns were not identical for these two matrices. The discrepancy between $\mathrm{THg}$ and $\mathrm{MeHg}$ distribution along the creek suggested that, in addition to $\mathrm{THg}$ distribution, the differences in biogeochemical characteristics among different sites (which affects $\mathrm{Hg}$ methylation and demethylation) are important role in determining $\mathrm{MeHg}$ distribution patterns.

\section{Chapter 4 Conclusions}

Higher mercury concentrations were found in the redoximorphic concentrations than in the redoximorphic depletions. The higher content of $\mathrm{Fe} / \mathrm{Mn}$ and organic matter was probably responsible for the higher $\mathrm{Hg}$ concentration in the redoximorphic concentrations. As expected, fine soil particles contained higher $\mathrm{Hg}$ compared with the coarse ones. The results obtained using thermal desorption and sequential extraction procedure suggested that $\mathrm{Hg}$ retained in the redoximorphic concentrations was less volatile and labile than $\mathrm{Hg}$ in the redoximorphic depletions. With regards to the speciation of $\mathrm{Hg}$ in the soil, $10-30 \%$ of $\mathrm{Hg}$ species appeared to be $\mathrm{Hg}^{0}$ and other "easily" 
vaporized $\mathrm{Hg}$ species whereas organic matter bound $\mathrm{Hg}$ fraction was the major form of $\mathrm{Hg}$ species (accounting for $50 \%$ of total $\mathrm{Hg}$ ).

Total mercury concentrations ranged from 50 to $45,000 \mathrm{ng} / \mathrm{g}$ while $\mathrm{MeHg}$ varied from 0.2 to $60 \mathrm{ng} / \mathrm{g}$ in the ORR soil and sediment samples. The observation of fairly high $\mathrm{THg}$ as well as $\mathrm{MeHg}$ concentrations indicated that this area still has severe $\mathrm{Hg}$ contamination problem, despite that some remedial measures were adopted in the past two decades. Both $\mathrm{THg}$ and $\mathrm{MeHg}$ concentrations varied remarkably depending upon different sampling locations and environmental matrices sampled. Clear spatial patterns were not present for $\mathrm{THg}$ distribution along the EFPC, suggesting that long-time discharge of $\mathrm{Hg}$ from the DOE facility has extensively spread $\mathrm{Hg}$ contamination in this area. Spatial patterns were observed for $\mathrm{MeHg}$ in soil and in sediment, although the patterns were not identical for these two matrices. The discrepancy between THg and $\mathrm{MeHg}$ distribution along the creek suggested that, in addition to $\mathrm{THg}$ distribution, the differences in biogeochemical characteristics among different sites (which affects $\mathrm{Hg}$ methylation and demethylation) are important role in determining $\mathrm{MeHg}$ distribution patterns. 


\section{Chapter 5 Future Work}

Additional work will be necessary to have a complete understanding of the mercury problems in the East Fork Poplar Creek. Additional samples might be helpful especially if the samples are closer to the actual Oak Ridge reservation. This could give a better understanding of the situation and condition of the total mercury released originally.

A greater number of samples and sampling areas might be needed and this might require the use of a more direct and easy to use technique such as the Direct Mercury Analyzer thus reducing sample preparation procedures and time.

The results obtained for methyl mercury concentrations indicate that a correlation exists between methyl mercury and total mercury concentration and location. In the future, to understand how the nature of that trend relates to the overall mercury contamination problem an in depth study should be conducted.

The interesting problem of mercury bioavailability should be considered. For example using soil from that area, and small fishs and a fish tank, a study could be performed on the amount of mercury absorbed by fish and how this could be related to a real natural environment. 


\section{REFERENCES}

Agency for Toxic Substances and Disease Registry (ATSDR), 1999. Toxicological profile, for mercury (Update). US Department of Health \& Human Services, ATSDR, Atlanta, GA.

Akagi, H.C., E.S.; Cortes-Maramba, N.; Francisco-Rivera, A.T. and Timbang, T.D, 2000. Health assessment for mercury exposure among school children residing near a gold processing and refining plant in Apokon, Tagum, Davao del Norte, Philippines. The Science of the Total Environment 259, 31-43.

Andersson, A., 1979. Mercury in Soils, in: Nriagu, J. (Ed.), The Biogeochemistry of Mercury in the Environment. Elsevier/North Holland Biomedical Press, New York, pp. 79-112.

Barnett, M., Harris, L., 1995. Characterization of Mercury Species in Contaminated Floodplain soils. Water, Air, and Soil Pollution 80, 1105-1108.

Barnett, M., Harris, L., 1997. Formation of Mercuric Sulfide in Soil. Environmental Science \& Technology 31, 3037-3043.

Barnett, M., Turner, R., 1995. Bioavailability of mercury in East Fork Poplar Creek soils. Internal Report No. Y/ER-215. Martin Marietta Energy Systems, Oak Ridge, TN.

Biester, H., Gosar, M., Covelli, S., 2000. Mercury Speciation in Sediments Affected by Dumped Mining Residues in the Drainage Area of the Idrija Mercury Mine, Slovenia. Environ. Sci. Technol. 34, 3330-3336

Biester, H., Muller, G., Scholer, H.F., 2002a. Binding and mobility of mercury in soils contaminated by emissions from chlor-alkali plants. The Science of The Total Environment 284, 191-203.

Biester, H., Muller, G., Scholer, H.F., 2002b. Estimating distribution and retention of mercury in three different soils contaminated by emissions from chlor-alkali plants: part I. The Science of The Total Environment 284, 177-189. 
Biester, H., Scholz, C., 1997a. Determination of Mercury Binding forms in Contaminated Soils: Mercury Pyrolysis versus Sequential Extraction. Environ. Sci. Technol. 31, 233-239.

Biester, H., Scholz, C., 1997b. Determination of Mercury Binding Forms in Contaminated Soils: Mercury Pyrolysis versus Sequential Extractions. Environ. Sci. Technol. 31, 233-239.

Bloom, N., Preus, E., Katon, J., Hiltner, M., 2003. Selective extractions to assess the biogeochemically relevant fractionation of inorganic mercury in sediments and soils. Analytica Chimica Acta 479, 233-248.

Bloom, N.S., Colman, J.A., Barber, L., 1997. Artifact formation of methyl mercury during aqueous distillation and alternative techniques for the extraction of methyl mercury from environmental samples. Fresenius' Journal of Analytical Chemistry $358,371-377$.

Bombach, G., Kombach, K., Klemm, w., 1994. Speciation of mercury in soils and sediments by thermal evaporation and cold vapor atomic absoprtion. Fresenius J. Anal. Chem. 350, 18-20.

Cai, Y., 2000. Speciation and analysis of mercury, arsenic, and selenium by atomic fluorescence spectrometry. TrAC Trends in Analytical Chemistry 19, 62-66.

Cai, Y., Cabrera, J.C., Georgiadis, M., 2002. Assesment of arsenic mobility in the soils of some golf courses in South Florida. The Science of the Total Environment 291, 123-134.

Cai, Y., Jaffe, R., Jones, R., 1996. Determination of organomercury compounds in aqueoues samples by capillary gas chromatography-atomic fluorescence spectrometry following solid-phase extraction. Analytica Chimica Acta 334, 251259.

Cai, Y., Jaffé, R., Jones, R., 1997. Ethylmercury in the Soils and Sediments of the Florida Everglades. Environ. Sci. Technol. 31, 302-305. 
Cai, Y., Jaffé, R., Jones, R.D., 1999. Interactions between dissolved organic carbon and mercury species in surface waters of the Florida Everglades. Applied Geochemistry 14, 395-407.

Cai, Y., Jaffe, R. and Jones, R. , 1997. Ethylmercury in soils and sediments of the Florida Everglades. Environmental Science and Technology 31, 302-305.

Cai, Y., Monsalud, S., Jaffé, R., Jones, R.D., 2000. Gas chromatographic determination of organomercury following aqueous derivatization with sodium tetraethylborate and sodium tetraphenylborate: Comparative study of gas chromatography coupled with atomic fluorescence spectrometry, atomic emission spectrometry and mass spectrometry. Journal of Chromatography A 876, 147-155.

Campbell, K.R., Ford, C.J., Levine, D.A., 1998. Mercury distribution in poplar creek, oak ridge, tennessee, usa. Environmental Toxicology and Chemistry 17, 1191-1198.

Carroll, G., Truman, C.R., 1995. J. Air Waste Managem. Assoc. 45, 730.

Clarkson, T.W., 1972. CRC Review in Toxicology. Chem Rubber Co., Cleveland, 203234.

Clarkson, T.W., 1992. Mercury: Major issues in environmental health. Environmental Health Perspectives. 100, 31-38.

Clarkson, T.W., Magos, L., 2006. The Toxicology of Mercury and Its Chemical Compounds. Critical Reviews in Toxicology 36, 609 - 662.

Clarkson, T.W., Strain, J.J., 2003. Nutritional Factors May Modify the Toxic Action of Methyl mercury in Fish-Eating Populations. J. Nutr. 133, 1539S-1543.

Cleckner, L., Gilmour, C., Hurley, J., Krabbenhoft, D., 1999. Mercury methylation in periphyton of the Florida Everglades. Limnology and Oceanography 44, 18151825.

Craig, J.P., 1986. Organometallic compounds in the environment. Wiley, New York. 
D.O.E, 1983. Mercury at the Y-12 Plant: A Summary of the 1983 UCC-ND Task Force Study. Contract No W-7405-ENG-26.

D.O.E, 1997. Mercury abatement report for the U.S. Department of Energy Oak Ridge Y12 Plant for fiscal year 1997,Lockheed Martin Environmental Restoration Program. ER-297, November 13, 1997.

Dudas, M., Pawluk, S. , 1976. The nature of mercury in chernozemic and luvisolic soils in Alberta, Canada. J. Soil Sci. 56, 413-423.

Environmental Reporter, 2000. Mercury from electric power plants to be regulated under Air Act. 31, 2654 2656.

Fitzgerald, W.F., Lamborg, C.H., Hammerschmidt, C.R., 2007. Marine Biogeochemical Cycling of Mercury. Chem. Rev. 107, 641-662.

Fitzgerald, W.F., Lyons, W.B., 1973. Organic Mercury Compounds in Coastal Waters. Nature 242, 452-453.

Fitzgerald, W.F., Watras, C.J., 1989. Mercury in surficial waters of rural Wisconsin lakes. The Science of The Total Environment 87-88, 223-232.

Gerlach CL, D.D., Miller E, Cardenas D, Singh AK, Page D, Combs D, Heithmar EM, 1995. Characterization of Mercury Contamination at the East Fork Poplar Creek, Oak Ridge, Tennessee - A Case Study. EPA/600/R-95/110, 1995.

Gilmour, C., Krabbenhoft, D., Orem, W., Aiken, G., Roden, E., Mendelssohn, I., 2006. Appendix 2B-2: Status Report on ACME Studies on the Control of Hg Methylation and Bioaccumulation in the Everglades. 2006 South Florida Environmental Report.

Gilmour, C.C., Henry, E.A., 1991. Mercury methylation in aquatic systems affected by acid deposition. Environmental Pollution 71, 131-169. 
Gilmour, C.C., Henry, E.A., Mitchell, R., 1992. Sulfate stimulation of mercury methylation in freshwater sediments. Environ. Sci. Technol. 26, 2281-2287.

Gilmour, C.C., Riedel, G.S., Edrington, M.C., Bell, J.T., Benoit, J.M., Gill, G.A., Stordal, M.C., 1998. Methylmercury concentrations and production rates across a trophic gradient in the northern Everglades. Biogeochemistry 40, 327-345.

Halbach, S., 1995. Toxicity of detrimental metal ions. In: Handbook of Metal-Ligand Interactions in Biological Fluids. Bioinorganic Medicine Vol.2 (Ed. G. Berthon), 640-643.

Han, F.X., Su, Y., Monts, D.L., Waggoner, C.A., Plodinec, M.J., 2009. Binding, distribution, and plant uptake of mercury in a soil from Oak Ridge, Tennessee, USA. Science of The Total Environment In Press, Corrected Proof.

Han, Y., Kingston, H.M., Boylan, H.M., Rahman, G.M.M., Shah, S., Richter, R.C., Link, D.D., Bhandari, S., 2003. Speciation of mercury in soil and sediment by selective solvent and acid extraction. Analytical and Bioanalytical Chemistry 375, 428-436.

Helander, B., Olsson, M. and Reutergardh, L, 1982. Residue levels of organochlorine and mercury compounds in unhatched eggs and the relationships to breeding success in white-tailed sea eagles Haliaeetus Albicilla in Sweden. Holarctic Ecol. 5, 349366.

Hintelmann, H., Hempel, M., Wilken, R.D., 1995. Observation of Unusual Organic Mercury Species in Soils and Sediments of Industrially Contaminated Sites. Environ. Sci. Technol. 29, 1845-1850.

Hollerman, W., Holland, L., Ila, D., Hensley, J., Southworth, G., Klasson, T., Taylor, P., Johnston, J., Turner, R., 1999. Results from the low level mercury sorbent test at the Oak Ridge Y-12 Plant in Tennessee. Journal of Hazardous Materials 68, 193203.

Holmes, J., Lean, D., 2006. Factors that influence methylmercury flux rates from wetland sediments. Science of The Total Environment 368, 306-319. 
Hosokawa, Y., 1993. Remediation work for mercury contaminated bay-experiences of Minamata Bay project, Japan. Water Science and Technology 28.

Jay, J.A., Morel, F.M.M., Hemond, H.F., 2000. Mercury Speciation in the Presence of Polysulfides. Environ. Sci. Technol. 34, 2196-2200.

Jensen, S., JernelÖV, A., 1969. Biological Methylation of Mercury in Aquatic Organisms. Nature 223, 753-754.

Jonasson, I.R., Boyle, R.W., 1972. Geochemistry of mercury and origins of natural contamination of the environment. Canadian Institute of Mining and Metallurgical Bulletin 65, 32-39.

Jones, R.D., Jacobson, M.E., Jaffe, R., 1995. Method development and sample processing of water, soil, and tissue for the analysis of total and organic mercury by cold vapor atomic fluorescence spectrometry. Water, Air, and Soil Pollution 80, 12851294.

Kambey, J.L.F., A.P. and Bendell-Young, L.I. , 1989. Determination of methlmercury in natural waters at the sub-nanograms per litre level by capillary gas chromatography after adsorbent preconcentration. Analytica Chimica Acta 221, 259-268.

Kim, C.S., Bloom, N.S., Rytuba, J.J., Brown, G.E., Jr., 2003. Mercury Speciation by Xray Absorption Fine Structure Spectroscopy and Sequential Chemical Extractions: A Comparison of Speciation Methods. Environ. Sci. Technol. 37, 5102-5108.

Kim, C.S., BrownJr, G.E., Rytuba, J.J., 2000. Characterization and speciation of mercury-bearing mine wastes using X-ray absorption spectroscopy. The Science of The Total Environment 261, 157-168.

Kot, F.S., Matyushkina, L.A., Rapoport, V.L., Dugina, I.O., 2001. Mercury Fractions in Natural and Urban Soils of the Middle Amur, Far East Russia. Bulletin of Environmental Contamination and Toxicology 67, 59-66.

Krabbenhoft, D., Hurley, J., Olson, M., Cleckner, L., 1998. Diel variability of mercury phase and species distributions in the Florida Everglades. Biogeochemistry 40, 311-325. 
Krabbenhoft, D.P., Fink, L.E., Olson, M.L., 2000. The Effect of Dry Down and Natural Fires On Mercury Methylation In The Everglades, in: Nriagu, J. (Ed.), Proceedings of the 11th Annual International Conference on Heavy Metals in the Environment, University of Michigan, Ann Arbor.

Kranzer, B., 2003. Everglades Restoration: Interactions of Population and Environment. Population \& Environment 24, 455-484.

Lindberg, S.E., Dong, W., Chanton, J., Qualls, R.G., Meyers, T., 2005a. A mechanism for bimodal emission of gaseous mercury from aquatic macrophytes. Atmospheric Environment 39, 1289-1301.

Lindberg, S.E., Southworth, G., Prestbo, E.M., Wallschlager, D., Bogle, M.A., Price, J., 2005b. Gaseous methyl- and inorganic mercury in landfill gas from landfills in Florida, Minnesota, Delaware, and California. Atmospheric Environment 39, 249258.

Lindberg, S.E., Wallschlager, D., Prestbo, E.M., Bloom, N.S., Price, J., Reinhart, D., 2001. Methylated mercury species in municipal waste landfill gas sampled in Florida, USA. Atmospheric Environment 35, 4011-4015.

Lindberg, S.E., Zhang, H., 2000. Air water exchange of mercury in the Everglades II: measuring and modeling evasion of mercury from surface waters in the Everglades Nutrient Removal Project. Science of the Total Environment 259, 135-143.

Liu, G., Cabrera, J., Allen, M., Cai, Y., 2006. Mercury characterization in a soil sample collected nearby the DOE Oak Ridge Reservation utilizing sequential extraction and thermal desorption method. Science of the Total Environment 369, 384-392.

Liu, G., Cai, Y., Kalla, P., Scheidt, D., Richards, J., Scinto, L.J., Gaiser, E., Appleby, C., 2008a. Mercury Mass Budget Estimates and Cycling Seasonality in the Florida Everglades. Environ. Sci. Technol. 42, 1954-1960.

Liu, G., Cai, Y., Philippi, T., Kalla, P., Scheidt, D., Richards, J., Scinto, L., Appleby, C., 2008b. Distribution of total and methylmercury in different ecosystem compartments in the Everglades: Implications for mercury bioaccumulation. Environmental Pollution 153, 257-265. 
Martin-Doimeadios, R., Wasserman, J., Donard , O., 2000. Chemical availability of mercury in stream sediments from the Almadean area, Spain. J. Environ. Monit 2, 360-366.

Mason, R.P., Abbott, M.L., Bodaly, R.A., Bullock, O.R., Jr, Driscoll, C.T., Evers, D., Lindberg, S.E., Murray, M., Swain, E.B., 2005. Monitoring the Response to Changing Mercury. Environ. Sci. Technol. 39, 14A-22A.

Mason, R.P., Benoit, J.M., 2003. Organomercury compounds in the environment, in: Craig, P.J. (Ed.), Organometallic compounds in the environment, 2nd ed. John Wiley \& Sons, Ltd., West Sussex, UK.

Mason, R.P., Fitzgerald, W.F., Hurley, J., Hanson, A.K., Jr., Donaghay, P.L., Sieburth, J.M., 1993. Mercury Biogeochemical Cycling in a Stratified Estuary. Limnology and Oceanography 38, 1227-1241.

Mason, R.P., Fitzgerald, W.F., Morel, F.M.M. , 1994. The biogeochemical cycling of elemental mercury: anthropogenic influences. . Geochimica Cosmochimica Acta 58, 3191-3198.

Mason, R.P., Kim, E.-H., Cornwell, J., Heyes, D., 2006. An examination of the factors influencing the flux of mercury, methylmercury and other constituents from estuarine sediment. Marine Chemistry 102, 96-110.

Mason, R.P., Lawson, N.M., Lawrence, A.L., Leaner, J.J., Lee, J.G., Sheu, G.-R., 1999. Mercury in the Chesapeake Bay. Marine Chemistry 65, 77-96.

Mason, R.P., Lawson, N.M., Sheu, G.R., 2000. Annual and seasonal trends in mercury deposition in Maryland. Atmospheric Environment 34, 1691-1701.

Mason, R.P., Sullivan, K.A., 1997. Mercury in Lake Michigan. Environ. Sci. Technol. 31, 942-947.

Monsalud, S., 1999. Determination of organomercury compounds in environmental and biological samples by using derivatization and chromatographic detection. M.S. Thesis, Florida International University, Miami, Florida. 
Morris, N.H., 1995. Mercury levels in dentists of reproductive age. British Dental Journal $179,47-47$.

Munthe, J., Wangberg, I., Iverfeldt, A., Lindqvist, O., Stromberg, D., Sommar, J., Gardfeldt, K., Petersen, G., Ebinghaus, R., Prestbo, E., 2003. Distribution of atmospheric mercury species in Northern Europe: final results from the MOE project. Atmospheric Environment 37, 9-20.

Murphy, D.M., Hudson, P.K., Thomson, D.S., Sheridan, P.J., Wilson, J.C., 2006. Observations of Mercury-Containing Aerosols. Environ. Sci. Technol.

Nagase H.; Ose, Y.S., K.; Ishikawa, T. , 1982. Methylation of mercury by humic substances in an aquatic environment. . The Science of the Total Environment 25, $133-142$.

National Institute of Environmental Health Science (NIEHS), 1998. Scientific issues relevant to assessment of health effects from exposure to methylmercury, Report of the Workshop on Scientific Issues Relevant to Assessment of health Effects from Exposure to methylmercury, Raleigh, NC.

National Research Council (NRC), 2000. Toxicological effects of methylmercury. National Academy Press, Washington, DC.

NRC, 2000. Toxicological effects of methylmercury. National Research Council), National Academy Press, Washington, DC,.

Nriagu, J.O., 1993. Legacy of mercury pollution. Nature 363, 589-589.

Nriagu, J.O., 1994. Mercury pollution from the past mining of gold and silver in the Americas. The Science of The Total Environment 149, 167-181.

Nriagu, J.O., Pfeiffer, W.C., Malm, O., Souza, C.M.M.d., Mierle, G., 1992. Mercury pollution in Brazil. Nature 356, 389-389.

Nuzzi, R., 1972. Toxicity of Mercury to Phytoplankton. Nature 237, 38-40. 
O'Driscoll, N.J., Evans, R.D., 2000. Analysis of Methyl mercury Binding to Freshwater Humic and Fulvic Acids by Gel Permeation Chromatography/Hydride Generation ICP-MS. Environ. Sci. Technol. 34, 4039-4043.

O'Driscoll, N.J., Rencz, A.N., Lean, D.R.S. (Eds.), 2005. Mercury Cycling in a WetlandDominated Ecosystem: A Multidisciplinary Study. Society of Environmental Toxicology and Chemistry (SETAC), Pensacola, FL.

Ogrinc, N., Monperrus, M., Kotnik, J., Fajon, V., Vidimova, K., Amouroux, D., Kocman, D., Tessier, E., Zizek, S., Horvat, M., 2007. Distribution of mercury and methylmercury in deep-sea surficial sediments of the Mediterranean Sea. Marine Chemistry 107, 31-48.

Pehkonen, S.O.a.L.C.-J., 1989. Oxidation of elemental mercury by aquatic chlorine $(\mathrm{HOCl} / \mathrm{OCl})$ : implications for tropospheric mercury chemistry. Journal of Geophysiscal Research 103, 28093-28102.

Pilgrim, W., Eaton, P., Trip, L., 2001. The Need for Integrated Linkages and Long-Term Monitoring of Mercury in Canada. Environmental Monitoring and Assessment 67, 57-68.

Pirrone, N., 2001. Mercury research in Europe: towards the preparation of the EU air quality directive. Atmospheric Environment 35, 2979-2986

Porcella, D.B., 1994. Mercury in the environment. In: (Ed. Watras, C.J., Huckabee, J.W.) Mercury as Pollution-Integration and Synthesis. CRC Press, 3-19.

Porcella, D.B., Ramel, C., Jernelov, A., 1997. Global Mercury Pollution and the Role of Gold Mining: An Overview. Water, Air, \& Soil Pollution 97, 205-207.

Rasmussen, P.E., 1994. Current Methods of Estimating Atmospheric Mercury Fluxes in Remote Areas. Environ. Sci. Technol. 28, 2233-2241.

Ravichandran M, A.G., Reddy MM, and Ryan JN, 1998. Enhanced dissolution of cinnabar (mercuric sulfide) by aquatic humic substances. . Environ. Sci. Technol. $32,3305-3311$. 
Renneberg, A.J., Dudas, M.J., 2001. Transformations of elemental mercury to inorganic and organic forms in mercury and hydrocarbon co-contaminated soils.

Chemosphere 45, 1103-1109.

Revis, N.W., Osborne, T., 1989. Distribution of mercury species in soil from mercury a contaminated site. Water, Air, and Soil Pollution 45, 105-113.

Sanchez-Uria, J.E.a.S.-M., A., 1998. Inorganic and methylmercury speciation in environmental samples. Talanta, 47 47, 509-524.

Schroeder, W.H., 1989. Developments in the speciation of mercury in natural waters. TrAC Trends in Analytical Chemistry 8, 339-342.

Schroeder, W.H., Munthe, J., 1998. Atmospheric mercury--An overview. Atmospheric Environment 32, 809-822.

Schroeder, W.H., Steffen, A., Scott, K., Bender, T., Prestbo, E., Ebinghaus, R., Lu, J.Y., Lindberg, S.E., 2003. Summary report: first international Arctic atmospheric mercury research workshop. Atmospheric Environment 37, 2551-2555.

Siciliano, S.D., Sangster, A., Daughney, C.J., Loseto, L., Germida, J.J., Rencz, A.N., O'Driscoll, N.J., Lean, D.R.S., 2003. Are Methylmercury Concentrations in the Wetlands of Kejimkujik National Park, Nova Scotia, Canada, Dependent on Geology? J. Environ. Qual. 32, 2085-2094.

Smith, W., Smith, A. , 1975. Minamata. Holt, Rinehart and Winston. New York.

Sorensen, J.A., Glass, G.E., Schmidt, K.W., 1994. Regional Patterns of Wet Mercury Deposition. Environ. Sci. Technol. 28, 2025-2032.

Stober, Q.J., Thornton, K., Jones, R., Richards, J., Ivey, C., Welch, R., Madden, M., Trexler, J., Gaiser, E., Scheidt, D., Rathbun, S., 2001. South Florida Ecosystem Assessment: Phase I/II (Technical Report) - Everglades Stressor Interactions: Hydropatterns, Eutrophication, Habitat Alteration, and Mercury Contamination. EPA 904-R-01-003. USEPA Region 4, Athens, GA. 
Stordal, M.C., Gill, G.A., Wen, L.S., Santschi, P.H., 1996. Mercury phase speciation in the surface waters of three Texas estuaries: Importance of colloidal forms. Limnology and Oceanography 41, 52-61.

Swain, E.B., Engstrom, D.R., Brigham, M.E., Henning, T.A., Brezonik, P.L., 1992. Increasing rates of atmospheric mercury deposition in midcontinental North America. Science 257, 784-787.

Thayer, J.S., 1984. Organometallic Compounds and Living Organisms. Academic Press Orlando, Florida.

Topping, G., Davies, I.M., 1981. Methylmercury production in the marine water column. . Nature, 243.

Tseng, C.M., Lamborg, C., Fitzgerald, W.F., Engstrom, D.R., 2004. Cycling of dissolved elemental mercury in Arctic Alaskan lakes. Geochimica et Cosmochimica Acta $68,1173-1184$.

Turner, A., Millward, G.E., Le Roux, S.M., 2001. Sediment-water partitioning of inorganic mercury in estuaries. Environ. Sci. Technol. 35, 4648-4654.

U.S.D.O.I., 1994. United States Department of Interior. Bureau of Mines. Mineral Industry Surveys, July 1994. EPA/625/R-00/002.

U.S.E.P.A., 1997a. Mercury Study Report to Congress, volumes I-VIII. Office of Air Quality Planning and Standards and Office of Research and Development. EPA452/R-97-003, Washington, DC.

U.S.E.P.A., 1997b. Mercury Study Report to Congress, volumes I-VIII. Office of Air Quality Planning and Standards and Office of Research and Development. EPA452/R-97-003, Washington, DC, .

U.S.E.P.A., 1997c. Vol II. An Inventory of Anthropogenic Mercury Emissions in the United States. United States Environmental Protection Agency. Mercury Study Report to Congress

U.S.E.P.A., 1997d. Vol III. Fate and Transport of Mercury in the Environment. United States Environmental Protection Agency. Mercury Study Report to Congress 
U.S.E.P.A., 1997e. Vol IV. An Assessment of Exposure to Mercury in the United States. United States Environmental Protection Agency. Mercury Study Report to Congress.

U.S.E.P.A., 1997f. Vol V. Health Effects of Mercury and Mercury Compounds. United States Environmental Protection Agency. Mercury Study Report to Congress.

U.S.E.P.A., 1997g. Vol VI. An Ecological Assessment for Anthropogenic Mercury Emissions in the United States. United States Environmental Protection Agency. Mercury Study Report to Congress.

U.S.E.P.A., 1997h. Vol VII. Characterization of Human Health and Wildlife Risks from Mercury Exposure in the United States. United States Environmental Protection Agency. Mercury Study Report to Congress.

U.S.E.P.A., 1997i. Vol VIII. An Evaluation of Mercury Control Technologies and Costs. United States Environmental Protection Agency. Mercury Study Report to Congress.

U.S.E.P.A., 1998. South Florida Ecosystem Asessment. Vol. I. Final Technical report Phase I. EPA-904-R-98-002. Office of Research and Development, US Government Printing Office, Washington DC.

U.S.E.P.A., 2000. Mercury research strategy. Office of research and Development. EPA/600/R-00/073.

U.S.G.S., 1998. Mercury contamination of aquatic ecosystems http://h2o.usgs.gov/public/wid/Fs216-95.html.

Uchino, E., Kosuga, T., Konishi, S., Nishimura, M., 1987. Determination of mercury in river water, rain, and snow. Environ. Sci. Technol. 21, 920-922.

Ullrich, S.M., Ilyushchenko, M.A., Uskov, G.A., Tanton, T.W., 2007. Mercury distribution and transport in a contaminated river system in Kazakhstan and associated impacts on aquatic biota. Applied Geochemistry 22, 2706-2734. 
Ullrich, S.M., Tanton, T.W., Abdrashitova, S.A., 2001. Mercury in the aquatic environment: A review of factors affecting methylation. Critical Reviews in Environmental Science and Technology 31, 241-293.

USEPA, 2002. Update: National listing of fish and wildlife advisories. EPA-823-F-02007. USEPA Office of Water, Washington, DC.

Wallschlager, D., Desai, M., 1998. Heavy Metals in the Environment. Mercury Speciation in Floodplain Soils and Sediments along a Contaminated River Transect. Journal of Environmental Quality 27, 1034-1044.

Wallschlager, D., Desai, M., Spengler, M., 1998a. How Humic Substances dominate Mercury geochemistry in contaminated floodplain soils and sediments. J. Environ. Qual. 27, 1044-1054.

Wallschlager, D., Desai, M.V.M., Spengler, M., Wilken, R.-D., 1998b. Mercury Speciation in Floodplain Soils and Sediments along a Contaminated River Transect. J. Environ. Qual. 27, 1034-1044.

Wallschlager, D., Desai, M.V.M., Spengler, M., Windmoller, C.C., Wilken, R.-D., 1998c. How Humic Substances Dominate Mercury Geochemistry in Contaminated Floodplain Soils and Sediments. J. Environ. Qual. 27, 1044-1054.

Watanabe, C., Satoh H. , 1996. Evolution of our understanding of methylmercury as a health threat. . Environmental Health Perspectives 104, 367-379.

Weber, J.H., 1993. Review of possible paths for abiotic methylation of mercury(II) in the aquatic environment. Chemosphere 26, 2063-2077.

Windmöller, C., Wilken, R., Jardim, W., 1996. Mercury speciation in contaminated soils by thermal release analysis. Water, Air, and Soil Pollution 89, 399-416.

Wood J.M., Kennedy, F.S., Rosen, C.E., 1969. Synthesis of methylmercury compounds by extracts of methanogenic bacteria. . Nature 220, 173-174. 